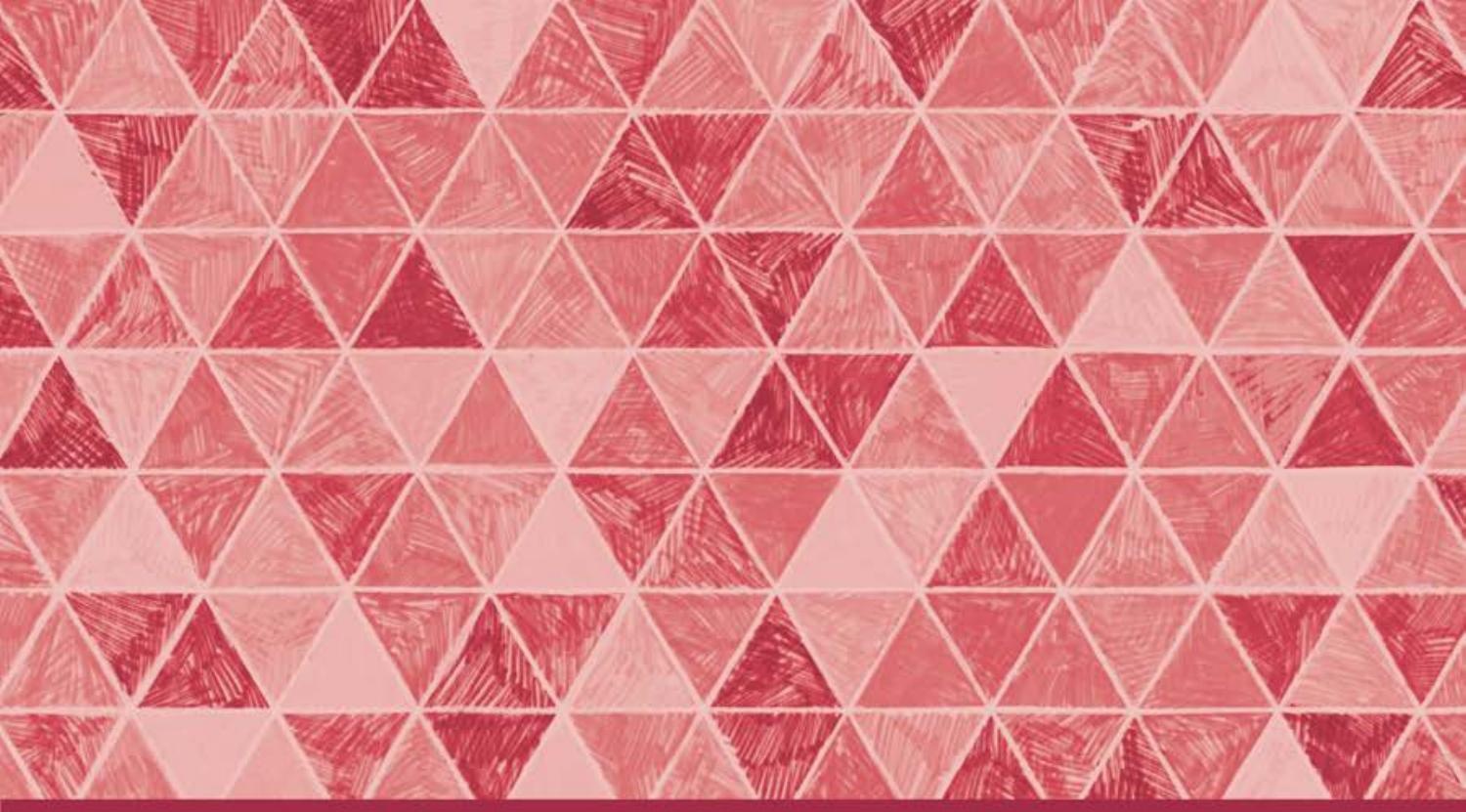

Routledge Research in Sport, Culture and Society

\title{
SPORTING CAPITAL
}

\section{TRANSFORMING SPORTS DEVELOPMENT POLICY AND PRACTICE}

Nicholas F. Rowe

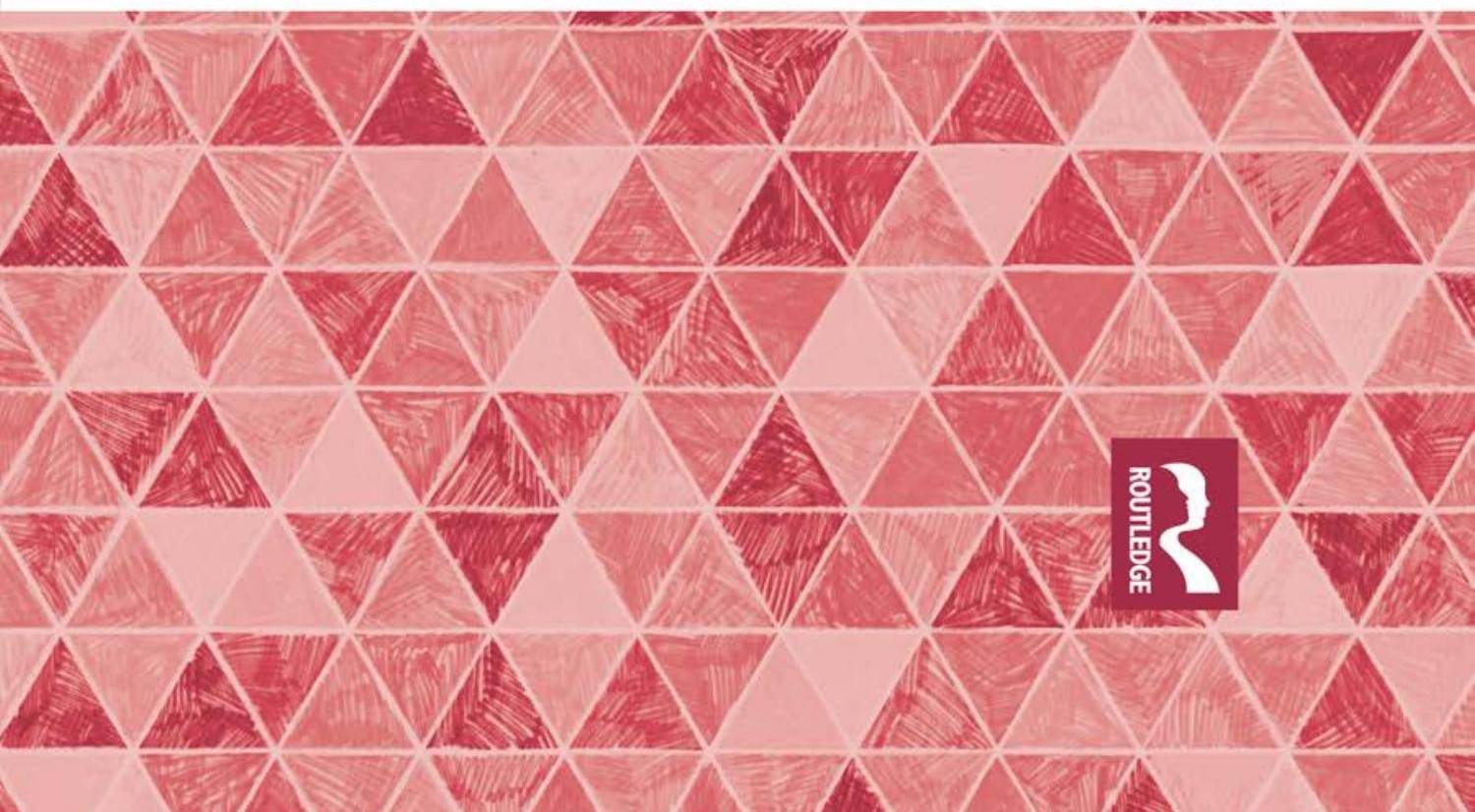




\section{Sporting Capital}

In a world of competing public policy priorities, economic challenges and political uncertainty, sports development organisations and initiatives need to adapt to survive. This book makes the case for 'Sporting Capital' as a new conceptual model of sports participation with the potential to transform public policy and practice in sports development.

The central argument presented is that a model of Sporting Capital - with its three domains of physiological, social and psychological attributes provides a missing framework, creating a new impetus for sustained growth in community sport by joining up the levels at which sports development is planned and implemented. Touching on important issues such as youth sport, public health, volunteering, disability, ethnicity and social inequality, it examines patterns of sports participation in relation to age, gender and social class and offers recommendations for strategic policy improvements that can be implemented by practitioners working on the front line of community sport.

Sporting Capital: Transforming Sports Development Policy and Practice provides valuable insights for all those interested in sports development, youth sport, community sport, or sport and social policy.

Nicholas F. Rowe is a freelance sport research consultant and Visiting Research Fellow at Leeds Becket University, UK. For nearly 30 years he worked for the GB Sport Council and Sport England, most recently as Sport England's Strategic Lead for Research and Evaluation. 
Routledge Research in Sport, Culture and Society

\section{Women Sport Fans}

Identification, participation, representation

Kim Toffoletti

\section{Sport in Korea}

History, development, management

Edited by Dae Hee Kwak, Yong Jae Ko, Inkyu Kang and

Mark Rosentraub

\section{Sport and National Identities}

Globalization and Conflict

Edited by Paddy Dolan and John Connolly

88 Sport and Contested Identities

Contemporary Issues and Debates

Edited by David Hassan and Ciaran Acton

89 Sport and Peace-Building in Divided Societies

Playing with Enemies

John Sugden and Alan Tomlinson

90 Fitness, Technology and Society

Amusing Ourselves to Life

Brad Millington

9 I Global Perspectives on Sports and Christianity Edited by Afe Adogame, Nick J. Watson and Andrew Parker

\section{Sporting Capital}

Transforming Sports Development Policy and Practice Nicholas F. Rowe

www.routledge.com/sport/series/RRSCS 


\section{Sporting Capital}

\section{Transforming Sports Development Policy and Practice}

Nicholas F. Rowe

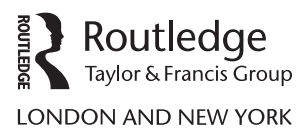


First published 2018

by Routledge

2 Park Square, Milton Park, Abingdon, Oxon OXI4 4RN

and by Routledge

7II Third Avenue, New York, NY 10017

Routledge is an imprint of the Taylor \& Francis Group, an informa business

(C) 2018 Nicholas F. Rowe

The right of Nicholas F. Rowe to be identified as author of this work has been asserted by him in accordance with sections 77 and 78 of the Copyright, Designs and Patents Act 1988.

All rights reserved. No part of this book may be reprinted or reproduced or utilised in any form or by any electronic, mechanical, or other means, now known or hereafter invented, including photocopying and recording, or in any information storage or retrieval system, without permission in writing from the publishers.

Trademark notice: Product or corporate names may be trademarks or registered trademarks, and are used only for identification and explanation without intent to infringe.

British Library Cataloguing-in-Publication Data

A catalogue record for this book is available from the British Library

Library of Congress Cataloging-in-Publication Data

A catalog record for this book has been requested

ISBN: 978-I-I38-290I7-4 (hbk)

ISBN: 978-I-3I5-26650-3 (ebk)

Typeset in Sabon

by Apex CoVantage, LLC 
To Sally and Thomas 
$\because$ Taylor \& Francis

Taylor \& Francis Group

http://taylorandfrancis.com 


\section{Contents}

Lists of figures $\quad \mathrm{x}$

Preface xiii

Acknowledgements $\quad$ xvi

1 Introduction 1

Structure of the book 10

2 The public policy challenge for community sport:

the need for a theoretically driven paradigm shift

The public policy challenge for sport 17

The need for a paradigm shift: establishing a stronger

theoretical foundation for community sports

development 25

3 Sporting capital - what is it, how does it relate to other forms of human, cultural and social capital and why is it important?

What is sporting capital? 33

How does sporting capital relate to other forms of

human, cultural and social capital? 35

What are the constituents of sporting capital, its characteristics and the implications for public policy and practice? 39

4 Theories of sport development and behaviour change why do we need yet another theory?

Theories of sport development 54

Theories of physical activity behaviour change 57

Sporting capital: a synthesis of sport and physical activity theories 61 
5 Sport participation over the life-course: linking the evidence to sporting capital theory

Sport through the life-course 68

The early socialisation process - starting young 72

The early learning motivational climate 77

The importance of fundamental movement skills 80

The importance of interpersonal relationships - socialisation

beyond the family 82

Barriers and constraints - the context for participation 85

An ageing population - sport participation into older age 88

Summary and conclusions 90

6 Sporting capital in England: from measurement process to painting the landscape

Measuring sporting capital - the Sporting Capital Index 103

How much more likely are people to participate in sport with increases in their levels of sporting capital? 107

Are we a sporting nation - what are the levels of sporting

capital in England? 109

The distribution of sporting capital by age, gender and social class 111

Summary and implications 114

7 Sporting capital in England: a level playing field? Exploring age, gender, social class, and sporting preferences

Sporting capital - a focus on age and gender 119

Sporting capital and social class - loading the dice for

sports participation? 126

Sporting capital and sporting preferences 132

Summary and implications 136

8 Building sporting capital: applying the theory to policy and practice

Introduction 141

Sporting capital: a strategic 'game changer' 144

Sporting capital - designing local interventions 150 
9 Where do we go from here? Applying, refining and testing the model of sporting capital

The need for 'strategic' research: improving our measurement and understanding of the theory of sporting capital 161 Intervention-based programme evaluation - what works to build sporting capital? 164

Sporting capital - where do we go from here? 170

Index 


\section{Figures}

2.1 Changes in participation rates in sport in England overall and by age 2005/6 to 2014/15 (participation defined as at least once a week of 30 plus minutes' duration moderate intensity sport)

2.2 Changes in participation rates in sport in England by gender and social class 2005/6 to 2014/15 (participation defined as at least once a week of 30 plus minutes' duration moderate intensity sport)

3.1 Model of sporting capital

3.2 Theoretical perspective on the relationship between sporting capital, external barriers to participation in sport and probability of participating (\%) (SCI is Sporting Capital Index score with 10 high and 1 low)

3.3 The 'Sports Participation Matrix'

3.4 Sporting capital theory of change

5.1 Participation rates in sport in England by age (16 plus) and gender. Participation is defined as at least once a week moderate intensity and at least 30 minutes' duration

5.2 Changes in participation: percentages saying they are doing the same, more or less sport than at the same time last year by quarter

5.3 Percentage of adults doing either more or less sport than they did at the same time last year by gender, age and social class

5.4 Views about sport and leisure - how strongly agreed or disagreed with each statement, by whether primary or secondary, and sex (MORI, 2003)

6.1 Questionnaire constructs used to measure sporting capital

6.2 Probability of participating in sport (at least once a week moderate intensity) with changes in the Sporting Capital Index Score (1 is low and 10 is high) in the English adult (16 plus) population 
6.3 Probability of participating in sport (at least once a week moderate intensity) with changes in the Sporting Capital Index score by age ( 1 is low and 10 is high) in the English adult (16 plus) population

6.4 Distribution of sporting capital (1 is low and 10 is high) in the English adult (16 plus) population

6.5 Sporting Capital Index mean score by age ( 1 is low and 10 is high) in the English adult (16 plus) population

6.6 Distribution of Sporting Capital Index scores by gender (1 is low and 10 is high) in the English adult (16 plus) population

6.7 Distribution of Sporting Capital Index scores by social class ( 1 is low and 10 is high) in the English adult (16 plus) population

7.1 Sporting capital mean scores ( 1 is low and 10 is high) by age and gender in the adult (16 plus) English population

7.2 Mean domain scores (on a scale of 1 to 10 with 1 low and 10 high) by age in the adult (16 plus) English population

7.3 Changes in the psychological relationship to sport in the adult (16 plus) English population. Net 'Index Scores' for selected question items in the Psychological domain (the net score is equal to the percent who agree 'it is very true for you' minus the percent who agree it is 'not at all true for you')

7.4 Mean domain scores (on a scale of 1 to 10 with 1 low and 10 high) by gender in the adult (16 plus) English population

7.5 Body confidence by gender in the adult (16 plus) English population. 'To what extent is it true for you ... I would be confident about the appearance of my body when taking part in sport or exercise activity'

7.6 Body confidence amongst the young in the English population. 'To what extent is it true for you ... I would be confident about the appearance of my body when taking part in sport or exercise activity'

7.7 'Sporting identity' by gender in the adult (16 plus) English population. 'To what extent is it true for you ... I would feel a real loss if I was forced to give up playing sport or from ever taking part in sport in the future'

7.8 Perceived sporting ability by gender in the adult (16 plus) English population. How would you rate yourself compared with people of your own age and gender ... General sporting ability and skills' 
7.9 'Social connections in sport' in the adult (16 plus) English population by gender. 'To what extent do you agree ... Most of my friends regularly take part in sport'

7.10 Changes in the probability of participating in sport (at least once a week) with changes in sporting capital - by social class. English adult (16 plus) population

7.11 Changes in sporting capital mean scores with age and social class in the adult (16 plus) English population

7.12 Changes in Sporting Capital Index (SCI) scores by age and social class in the adult (16 plus) English population. (Scores are on a collapsed 5-point scale with 1 and 2 combined (a low SCI score) and 4 and 5 combined (a high SCI score)

7.13 Mean domain scores (on a scale of 1 to 10 with 1 low and 10 high) by gender in the adult (16 plus) English population

7.14 Self confidence in sporty situations by social class in the adult (16 plus) English population. 'To what extent is it true for you ... I feel completely confident and at ease in situations where people take part in sport or exercise activity'

7.15 Social connections to sport by social class in the adult (16 plus) English population. 'To what extent do you agree ... Most of my friends regularly take part in sport'

7.16 Probability of participating in sport for different frequencies with changes in the Sporting Capital Index score ( 1 is low and 10 is high) in the adult (16 plus) English population

7.17 Probability of participating by type of sport (at least once a month) with changes in the Sporting Capital Index score (1 is low and 10 is high) in the English adult (16 plus) population

7.18 Probability of participating in swimming and cycling (at least once a month) with changes in the Sporting Capital Index score ( 1 is low and 10 is high) in the English adult (16 plus) population

7.19 Distribution of sporting capital levels across different types of sport (on a scale of 1 is low and 5 is high) in the English adult (16 plus) population

8.1 Guidance on intervention design referenced to individual Sporting Capital Index scores

9.1 Project intervention logic model: building sporting capital 167

9.2 A multi-method approach to project evaluation 


\section{Preface}

Sport has always featured not just as an important part of my life but as something that has defined and shaped it. It has been integral to my sense of who I am and what I do. It has given me, and continues to give me, a deep unending well of enjoyment from both the pleasure of playing and from the camaraderie of time spent with people who share that pleasure with me. Beyond dominating my spare time leisure activities, I have been fortunate enough for sport to reach into my professional career having worked for nearly 30 years in a national strategic sports development organisation and now as a consultant to influence and shape community sport-related research.

Reflecting on my own biography, my earliest memories are of my father playing football, my mother winning the 'Mum's race' at our primary school sports day and sport in all its shapes and forms being a constant topic of family conversation. As I reached junior and then secondary school age I was picked to play in a wide range of school teams, played and watched football with my Dad and spent most of my spare time outdoors either hitting or kicking a ball. In my mid teens I encouraged my Dad to play golf with me and he never looked back!

At University I found many distractions that temporarily took me away from regularly playing sports but always knew that I would return to take part when the time was right. As I got older my interests shifted from team sports to marathon running and to playing golf. And now in my retirement from full time working I have found time to challenge myself in new ways by cycling around the coast of Britain, keeping myself ticking over with regular 'jogs' in the countryside and spending even more time at my local golf club playing, officiating and contributing in various voluntary capacities.

Why am I sharing this with you? It is to make the important point that my experience is far from unique. Hundreds of thousands of people in this country and millions of others worldwide have had the same experience of sport in their lives and for a relatively small number participation in sport has been their source of income and livelihood. I suspect, like me, they never really questioned from a personal biographical perspective why sport 
in all its forms from participating to spectating at live events, from watching on television to reading in newspapers and, for me, 'researching' and writing a book about it, came to be so central in our lives.

But what made it unthinkable for me that I wouldn't be taking part in sport throughout my life? At a personal level for many years it was a question that I never really dwelt upon. However, in my professional capacity the question of what distinguished people like me who find it difficult to stop taking part in sport from those who it is almost impossible to make participate began over recent years to dominate my thinking. This thinking culminated in my ideas around 'sporting capital'. Sport is a central part of my life and something that has given me so much enjoyment only because I have had the capacities to enjoy it and to get the most from it. Those capacities are not simple or easy to define but they may be summarised into the three 'Cs' of competence, confidence and connections. My early life experience, in the family, at school and with my peers equipped me with the basic skills and confidence needed to enjoy a wide range of sports. My experience over the years has built on that foundation to provide positive and reinforcing feedback that has maintained and enhanced this 'stock' of capacities. I have drawn on this stock to overcome the constraints and barriers that life can put in the way. The motivation to take part in sport has prevailed in the face of all the obstacles thrown at me at different stages in my life.

However, my experience is not universal. For far too many, sport is something they find threatening, difficult, intimidating and unrewarding. It is something they tolerated at school but as soon as the opportunity arose it is something of which they steered well clear. For many others sport was something that was ok to do when they were young but wasn't sufficiently enjoyable to prioritise and persist with into adulthood. Their stock of capacities to take part in sport were low and over time got lower still as they became more socially and physically distanced from sport as an active pursuit. For people like me it is difficult to understand how these people feel about sport. In a public policy context there is a danger that this lack of empathy is institutionalised in the organisations that are run by sport enthusiasts who believe that everyone would take part in sport if only the opportunity was made available to them.

It was the realisation, informed by a combination of personal and professional experience, that the motivation to take part in sport is driven by a kind of invisible 'capital' that people carry around with them that started to open my eyes to the power of this idea. That this capital is similar in kind and connected to other cultural, social and human capitals helped the idea take form and develop. In this book I have sought to take the idea of sporting capital and build it into a coherent theoretical framework that I believe has the potential to create a paradigm shift in the way public policy for community sport is conceived and implemented. I say this advisedly and without in any way seeking to diminish the challenges involved of which I am fully aware. 
Writing this book has involved a journey of self reflection, critical analysis and a test of logic and personal application. The ideas expressed are in no way meant as a denunciation of all the efforts of those who have worked in sports development over the last 40 years or so, including of course my own. In fact there are many examples over those years where interventions have embraced aspects of sporting capital without assigning that label to them and without being interpreted and understood within its wider theoretical framework. However, I do believe that public policy has been held back in its potential effectiveness by lacking the coherent theoretical framework that sporting capital offers. And I believe that application of the theory could have a transformative impact on how we prioritise interventions in sport, how we design those interventions and crucially how we train and educate the workforce both paid and voluntary who are at the forefront of delivering on those interventions.

In this book I have talked about an ambition of 'sporting capital for all'. It is a vision where everyone no matter what age, what background or gender has the basic physical skills to take part in sport in ways that are rewarding, has the self confidence and 'can do' attitude that motivates and maintains participation throughout their lives and has access to the social connections and reinforcing social contexts that values and supports participation. In an ideal world these physically, sport literate people will have high quality infrastructure and environments that support and nurture their engagement. Those who chose not to take part in sport perhaps because they see other aspects of their lives and use of their capabilities in those areas more rewarding will make that choice from a position of strength and not weakness. This is to view sporting capital as a form of empowerment and not as one of individual deficit or limitation.

My ambition in this book has been to challenge received wisdom by starting a debate that will lead to change. There are many routes by which change can occur. It can be bottom up or top down, it can be directive or experiential, it can be incremental or revolutionary. This book is far from definitive on this count. Sporting capital as a theory is not fully tested and many of its propositions require further research. However, I believe a synthesis of the evidence available supports its plausibility and potential to breathe new life and sense of purpose into community sports development and enhance its justification in a world of competing priorities and challenging public policy environments. I hope at the very least that the readers of this book will reflect on its key messages to challenge their ways of thinking, how they behave and relate to others in their own personal lives and, if like me they are fortunate enough to work in community sports development, to help shape and influence what they do professionally to bring about transformative change.

Nicholas F. Rowe 


\section{Acknowledgements}

The antecedents to this book go back a long way. It would not have been possible without the good fortune I had to be recruited as a research assistant many, many years ago at the then G. B. Sports Council by Mike Collins and Arthur Dye. I couldn't have asked for better mentors to induct me into the world of sport, social policy and research. They are both sorely missed and I owe them a great debt of gratitude.

My colleagues over many years in the Sport England Research Team have all played their part - they know who they are and it would not be right for me to single them out. But I thank them all for their inspiration, support, intelligence and dedication. They were influential in shaping the ideas that I have presented in this book, wittingly or unwittingly, although I absolve them of any responsibility for them.

In the nearly 30 years I worked in national sports research my paths crossed with many inspirational people. There are four, however, that I would like to thank in particular, Professors Chris Gratton, Peter Taylor, Fred Coalter and Jonathan Long. In their own inimitable ways they have all influenced and challenged me over the years, although I would also like to think that at times I might have challenged them.

I would like to express my thanks to StreetGames UK and in particular to Ceris Anderson and Jane Ashworth for their support in commissioning the original research that made this book possible. The primary research reported in Chapters 6 and 7 draws heavily on earlier work I carried out for them (www.streetgames.org/resource/sporting-capital-and-doorstep-sportworking-build-legacy-sports-participation-england) and I appreciate their permission to use it in the context of this book. I would also like to thank Oliver Nordern and Joel Williams who while at TNS-BMRB carried out the modelling work to build the Sporting Capital Index.

My thanks also to Leeds Beckett University where in my position as a Visiting Research Fellow they have given me access to their bibliographic resources without which this book would not have been possible. Also thanks to Simon Whitmore, Cecily Davey and the team at Routledge for 
having the vision that a book on Sporting Capital was possible and helping me bring it to fruition.

Last but not least I would like to thank Sally Hall as a sounding board for my ideas, for putting up with my need for constant approval and for bringing her librarian skills to bear on helping me with the task of referencing and indexing material. 
$\because$ Taylor \& Francis

Taylor \& Francis Group

http://taylorandfrancis.com 


\section{Introduction}

This book is about an idea. The idea is conceptualised in two simple words, 'sporting capital'. But contained in these two words are multiple layers of meaning that span subject matter as diverse as individual human behaviour, motivational psychology, physical motor development, pedagogy, political sciences, philosophy, cultural studies and social policy. Sporting capital is not an abstract idea, but is an idea with a purpose in the sense that it is 'a thought or suggestion as to a possible course of action'. In writing this book I have taken the germ of this idea to build a coherent theory defined as 'a set of principles on which the practice of an activity is based'. Theories evolve and are there to be tested and challenged in the real world. The theory of sporting capital provides a framework for empirical research and a guide to policy and action. It is a theory that is very much in its infancy insofar as it has yet to undergo thorough 'road testing'; but all theories have to start somewhere, and those putting them forward must, with an open mind, be prepared to take some bumps and bruises along the way. As we go down that road I anticipate healthy and constructive criticism but am optimistic that sporting capital will emerge as a theory whose time has come.

In the contested world of 'sports development' (Houlihan and White, 2002; Collins, 2010a; Houlihan and Green, 2011; Hylton, 2013) I have come to the view, after more than 25 years of working at a national level bridging public policy and research, that the lack of a coherent theoretical foundation has limited its impact and by inference undermined its justification. These may be harsh words, but the evidence, referred to in Chapter 2, of the decades of stagnation in participation rates in sport and the apparent inability of governments, policy makers and practitioners to make significant inroads into structural social inequalities associated with age, gender, class, ethnicity and disability support this contention. This is despite substantial investment of public monies combined with the undoubted efforts of many well-meaning individuals, amongst whom I include myself, who believe and continue to believe in the transformative power of sport, the justification for state intervention and its ability to make a difference. Coalter (2007b, p. 7) makes reference to the need to "de-mythologize sport" 
and refers to "the sport evangelists who have invested much in their professional repertoires". In this book I am replacing this fuzzy mythological and evangelical narrative policy framework with one that is coherent, testable, capable of rational argument and, crucially, offers the potential to deliver results on the ground. In doing so I am hoping to take the surplus emotional power of sport and all those who promote it and harness it into a shared and effective theoretical framework for action.

I am aware that sporting capital as a theory will be open to the academic challenge of being reductionist in the pejorative sense of this word. And yes, it is possible to present sporting capital as a straightforward intuitively attractive idea. However, rather than apologising for its simplicity I would argue that this is a necessary attribute if theory is to be translated into an effective call for action. The apparent simplicity of the theory is, I believe, a strength and not a weakness. I would counter the reductionist argument by contending that behind its simplicity the theory is embedded with a sophisticated recognition of the complex systems (multiple not singular) that impact and interact to shape human sporting behaviour. At one level sporting capital is a micro theory that relates to the individual, his or her identity, predispositions, motivations, personal qualities, physiology and preferences. At a meso level sporting capital is about parental, family and peer influence, local institutional contexts, pedagogical frameworks, neighbourhoods and communities and local environments. At a macro level it is about broader socio-cultural contexts, shared value systems, national identities, public welfare and quality of life. In this sense sporting capital may be characterised as spanning and synthesising a 'society in leisure' approach which draws on structural forms of explanation and a socio-psychological approach that focuses on individual motivations, benefits and satisfactions (Coalter, 1997).

This intersection of disciplines and geographies is, I believe, an inherent strength of the theory. But it poses in turn a particular challenge for the author. I do not claim expertise across this multiplicity of disciplines, very few if any could, and I apologise in advance to any readers with specialist knowledge in any given area. My ambition in this book is big but it is limited. It is to provide an introductory narrative, supported by an initial foray into empirical evidence, for the idea of sporting capital at a level that is intellectually sound, intuitively compelling and that translates into an agenda for change and action. In order to do this I weave together a number of threads from a range of disciplines but only insofar as they are relevant to my general thesis on sporting capital. Readers who want text book, discursive and or critical overviews in say the political context of sport development and its history (Houlihan, 1997; Gratton and Henry, 2001; Houlihan and White, 2002; Houlihan, 2014; Houlihan and Lindsey, 2014; Grix and Phillpots, 2014; Grix, 2016), the psychology of sport, exercise and physical activity (Biddle and Mutrie, 2008; Weinberg 
and Gould, 2015), the sociology of sport (Giulianotti, 2005; Maguire et al., 2002; Jarvie and Thornton, 2012), sport pedagogy (Kirk, Macdonald and O'Sullivan, 2006; Tinning, 2008; Armour, 2013) and international comparative experience (Van Bottenburg, Rijnen and van Sterkenburg, 2005; Nicholson, Hoye and Houlihan, 2011; Hoekman, Breedveld and Scheerder, 2011; Van Bottenburg and De Bosscher, 2011; Hallmann and Petry, 2013) should look elsewhere.

My hope is that those in the academic world pick up the gauntlet to establish an evidence base that challenges and builds the theory in the contexts and disciplines in which their expertise lies, and ideally in multi and interdisciplinary collaborative research frameworks. But beyond this, and crucially linked to it, my ultimate ambition, and the reason I have written this book, is the hope that the theory will be used in applied settings by those who shape local policy and practice and by those who deliver it at the 'front line'. Their experience of how the theory can be applied to practice, what works, how and why and in what context is crucial and I pick this issue up in the final chapter. I am a realist, however, and although I would prefer to see a national sport development framework with sporting capital at its core driven by a growing evidence base, I recognise that change in this direction, if it occurs at all, is likely to be a slow, messy and incremental process. My experience to date in sharing my ideas with local sports development practitioners, for example in South and West Yorkshire, has been a positive one stimulating constructive debate and an appetite to translate the theory into practice. It encourages me to believe that a 'bottom up' approach, if that is indeed what is required, to influence a paradigm shift in national policy is certainly not out of the question.

Of course some would say that sporting capital is not a new idea, and I would agree that none of its constituent parts are 'new'. Other researchers have emphasised the interdependencies and impact of intrapersonal, biological/physical, psychological, social and structural/ecological factors in the decision to participate in sport (see for example: Henderson, 2009; Sallis, Owen and Fisher, 2008; Bailey et al., 2010). Stuij (2015) in research on the impact of different social class backgrounds on young people's socialisation into sport makes reference to 'sporting capital' as a form of cultural capital linking it to Bourdieu's concept of the habitus. It would be surprising if nearly half a century of public policy focus and research had not yielded such insights and relationships. I do believe, however, that as a coherent theoretical perspective that can facilitate a radical shift in public policy, sporting capital theory as presented here brings something significant and new to the table. In Chapter 4 I examine other theories that have at times surfaced in the policy context of sport, and conclude that at best they are partial, in some cases more descriptive than explanatory and in others cases ill-fitting when borrowed from other fields, particularly and currently, those of behaviour change and physical activity. 
In the 28 years I worked at Sport England rarely did a month pass where we didn't have anguished discussions about the scope and meaning of the word 'sport'. As Coalter (2007b, p. 7) says, "sport is a collective noun which hides much more than it reveals. ... There are almost endless variations of sport processes, mechanisms, participants and experiences". The COMPASS project (UK Sport, 1999), examining comparative participation rates in different European countries, found that one of the greatest conceptual and practical difficulties encountered in attempting to make meaningful international comparisons of participation in sport concerns the way sport is defined. These national variations in definition are as much a consequence of cultural differences in the understanding of what sport is as they are about how the measurement of sport is operationalised. Van Bottenburg, Rijnen and van Sterkenburg (2005, p. 15) in their analysis of sport trends across the European Union made the observation that,

Sport has become a strongly differentiated and diffuse phenomenon, which is practiced for many different ends, in diverse ways and in divergent contexts and organisational forms. How people experience sport is also related to this. More than ever before, people have the tendency to label their activities as 'sport'. This is furthered by the fact that sport has been 'upgraded' in both a social and cultural sense during the past few decades. One of the consequences of this is that sport in the year 2004 encompasses a broad spectrum with the Olympic games at one extreme, as the ultimate manifestation of organised competitive sport, and at the other, all kinds of physical activity that people (in contrast to fifty years ago) perceive as sporting behaviour.

Variously through the last 30 years or so the scope and definition of sport in England, at least as it applies to government policy, intervention and measurement, has swung between a very wide one that encompasses practically anything that moves (Council of Europe, 1992) to one that is more narrowly defined to exclude for example walking and certain types of cycling and or certain types of games such as darts or other activities that didn't meet thresholds of physical intensity (Sport England, 2004, 2008). Of course there is no absolute right or wrong answer. As referenced above, sport is a cultural phenomenon; for example in some countries bridge, a card game, and chess, a board game, are defined as sport, in Finland 'hunting moose' is a sporting activity. However, the scope of the definition of sport in a policy context cannot be ignored as it impacts on its policy leverage and impact. For example a very wide definition of sport embracing physical activity extends its relevance to public health and specifically to the obesity policy domain increasing potential funding opportunities and political influence. However, such a wide definition also increases the potential for sport policy to lose its focus, to dilute its impact by spreading investment 
too thinly and to undermine its relationships with its more traditional core constituencies and stakeholders. These tensions and dilemmas undoubtedly go a long way to explain the yo-yoing of national sport policy over the last 30 years or so between 'big sport' and 'smaller sport' policy domains.

It is important that I make clear from the outset that sporting capital is unapologetically a 'sport policy theory' rather than a physical activity theory. The salience of the theory to sport is its strength, not its weakness. One of the three pillars (domains) of sporting capital is the social connections that people have in and through sport which in turn encompasses the institutional context for sport in the broadest sociological sense. Sporting capital as a theoretical construct applies in particular, but not exclusively, to all 'organised sport' even if that organisation is limited and outside of for example a formal club setting. It includes in its scope team sports, individual sports, recreational walking, recreational cycling, road running and a wide range of health and fitness activities. However, it is less applicable to physical activities where the motivation is concerned with other instrumental outcomes such as DIY or housework, transport as a primary purpose, gardening or other hobbies or artistic activities that have a physical component (see Khan et al., 2012, p. 60 for a useful conceptual model of the relationship between sport, exercise and physical activity). Although sporting capital has an application to elite sport performance insofar as a pre-condition of becoming an elite athlete is an initial developmental process to build high levels of sporting capital, the focus of the theory is not at this level. It is, however, worth noting the link made in Chapter 3 where I discuss the transferability of 'capitals' and how, for elite professional sports people, sporting capital becomes one and the same as 'human capital' insofar as it is marketable and acquires economic value.

The apparent cyclical shifts in how sport is defined in public policy have been at least matched by the concurrent shifts in the rationale for public investment in sport (see for example: Coalter, Long and Duffield,1988; Coalter, 2007a; Coalter, 2007b; DCMS and Strategy Unit, 2002; Collins, 2010b; Grix and Carmichael, 2012). It could be argued that the justification for public investment in reality lies somewhere on a spectrum between at one end what has been termed 'sport for sports sake' to at the other end 'sport for good' i.e. sport as an instrumental means to achieve other social, educational, economic and public health outcomes. The political context in which sport policy is acted out has perhaps inevitably presented national sport policy as unequivocally at one or other end of this spectrum although the reality is always more nuanced. Hylton and Totten (2008) suggest that sports development intervention exists along a continuum that ranges from at one extreme an emphasis that is purely sport-related development outcomes to at the other extreme initiatives that are predominantly focused on community well-being. It could be argued that this politicisation process of sport policy with five to 10 yearly seismic shifts in positioning, at least in 
the rhetoric of sport if less in the reality, has worked to the overall detriment of achieving sustained impacts on mass participation or delivering wider public policy outcomes (Houlihan, 2011; Collins, 2010b).

Recent experience is illustrative. Sport England was categorical in its '2008 to 11 Strategy' that it was 'sport first' and 'health and other outcomes second',

In the future Sport England's role will be to focus exclusively on sport. Sport can and does play a major role in achieving wider social and economic benefits - notably on the health front. However, the driving force behind the strategy and investment is to address the needs of sport participants across the country. This provides a clear distinction with the physical activity agenda being driven by a number of departments, including the Department of Health and Department of Transport.

(Sport England, 2008, p. 1)

Eight years on, post the London Olympic Games and missed sport participation legacy targets, the latest Government and Sport England strategies (H. M. Government, 2015; Sport England, 2016) have swung the pendulum firmly back towards both a very wide definition of 'sport', which extends well into the informal domain of physical activity, and an instrumental 'sport for good' orientation. This shift is presented unequivocally by the Minister for Sport in her foreword where she states,

At the heart of this new strategy sit five simple but fundamental outcomes: physical health, mental health, individual development, social and community development and economic development. It is these outcomes that will define who we fund, what we fund and where our priorities lie in future. It sets the pathway for sport and physical activity for the next decade and beyond.

(H. M. Government, 2015, p. 1)

An outside interested observer might be less sanguine about the longevity of this newest emphasis in public policy for sport.

It is important to understand where sporting capital theory sits in relation to these changing policy contexts. We need to be clear that 'sporting capital' exists in the same way that say human capital exists, independent of whether government prioritises it, invests in it, values it in its own right or values it as a means to achieving something else. Sporting capital provides the fundamental building blocks that underpin individual motivation to take part in sport. Whether the rationale stops at sport for its own sake or extends beyond this to sport for good, building sporting capital is the primary means to achieving both these ends and in the latter case has the added benefits associated with the transferability of capitals. The simple logic is as follows: 
government intervention to increase sporting capital and extend its reach to a wider cross section of people leads to more sustained participation which in turn leads to improved health, education, social cohesion, economic benefit and so on. Of course this simple logic is in reality far from simple and is beset with issues of cause and effect, claims, counter claims and 'over claims' and with what Coalter (2007b) has termed the issue of 'necessary and sufficient conditions'.

The principal position that I take in this book is that: 1) having the requisite level of sporting capital is a necessary condition to participate in sport at all and particularly to do so over the life-course; 2) that, left to their own devices most people in advantageous social, economic and cultural contexts will build high levels of sporting capital and participate in sport regularly throughout their lives with all the attendant benefits that this brings; 3 ) that many people in less advantageous circumstances will live their lives having never achieved the levels of sporting capital that makes participation in sport an attractive proposition that sustains their interest and engagement; 4) that many more who achieve modest levels of sporting capital experience slow attrition in those levels over time as age, life transitions and external barriers intervene to the point that militates against participation; and 5 ) that public policy intervention can, if directed in the right way, lift the level of sporting capital amongst those who would otherwise fall below the threshold required to engage or re-engage in active and sustained participation in sport.

The focus of this book is on sport policy in England and that is where the majority of my personal experience lies. However, over the years in the context of my research with Sport England I have been engaged in extensive European wide debates on sport policy particularly as it impacts on levels and patterns of sport participation and related social trends (UK Sport, 1999). Where appropriate I occasionally refer to these wider European experiences and draw on evidence from outside Europe. For those readers from beyond these shores I would emphasise the universal nature of sporting capital as a theoretical construct. Although socio-cultural contexts vary from country to country, the building blocks of sporting capital as they apply to each individual remain the same albeit with limitless permutations. However, to the extent that levels of participation in sport are different in different countries it is reasonable to postulate that overall aggregate levels of sporting capital also vary. In Chapter 6 I present statistics on the levels of sporting capital in England. My hypothesis, as yet untested, is that a similar study in say Sweden, Finland, Denmark or Norway where participation rates are higher than in England would reveal higher aggregate levels of sporting capital across the population and importantly higher levels amongst women, ethnic minorities and lower socio-economic groups. Once established, unpicking and understanding the root causes of these differences would provide useful comparative insights that could support more 
effective public policy intervention in all countries concerned and I discuss this more fully in Chapter 9.

I firmly believe that there are clear, tangible recommendations emerging from sporting capital theory that are relevant to policy and practice. At a macro level the theory challenges prevailing policy emphases that have focused on supply, increasing opportunity, simplistic views on social marketing, the impact of major events and influence of role models, at the expense of more sophisticated demand side and individual capacity building intervention. The theory also has a lot to say about the structural inequalities in sports participation that relate in particular to social class and gender and their antecedents. At a micro level, through better profiling and assessment of individual levels of sporting capital, project designers and practitioners will be better able to intervene in ways that engage and meet individual needs based on current levels of sporting capital (see Chapters 8 and 9). This will impact, for example, on the types of sports and fitness activities offered, the style of delivery, including levels of competition and emphasis on intrinsic and or extrinsic motivational delivery, and the mix of gender and abilities in groups and teams. At its heart, however, sporting capital theory is not just a theory confined to individual behaviour change but embraces a system wide approach to intervention which integrates national policy with social and environmental circumstances, institutional frameworks and personal values, beliefs and traits (see Chapter 3). To this extent sporting capital theory sits within the broader socio-ecological model of behaviour referenced earlier in this chapter.

It is important to clarify what may be considered omissions from this book. The theory of sporting capital is, I would contend, a universal one insofar as whatever the context and circumstances that might apply sporting capital exists as embodied characteristics and capacities that impact on an individual's sporting behaviours. Everybody has a certain level of sporting capital although the permutations of the building blocks of that capital in relation to the psychological, physiological and social attributes and capabilities are unlimited. In this book I have focused my attention on the relationship between sporting capital, age, gender and social class as significant structural factors in society with known relationships to participation in sport. I have purposefully omitted any detailed reference to the importance and impact of sporting capital on sporting behaviours of people with a disability not because I in any way have placed this as a lower priority but because I would be unable to do the subject matter justice in the context of this book. I have in Chapter 9 made reference to the importance of prioritising research to further explore this relationship between sporting capital and participation in sport. Similarly I have omitted specific exploration or empirical analysis of the relationship between sporting capital and participation in sport by people from different ethnic groups or of people 
with different sexual orientations. Again this is not to deny or devalue that relationship or its importance as an area of public policy but has been made to avoid drawing superficial conclusions particularly where they are limited by the empirical measures that define these groups in standardised ways that do not reflect their homogeneity and the different cultural contexts that influence their behaviours. This concern is highlighted by Long et al. (2009, p. 57) in their systematic review of the literature on Black and other ethnic minorities and sport,

The constant cry from the researchers is for policymakers to recognise such differences and not treat minority ethnic groups as a homogeneous category. In particular the research stresses the importance of listening more closely to particular cultural and religious needs, such as those of some South Asian women, while recognising that these needs are not representative of all South Asian women.

In closing this introduction let us not forget in our academisation of sport that at a recreational and mass participation level it is driven by the sheer pleasure and enjoyment it brings. Enjoyment is derived from the mastery of skills, by overcoming personal challenges, stretching oneself physically and mentally, working collaboratively as part of a team or just being with friends and, for some, from satisfaction and or status associated with competitive success. (Wankel and Kreisel, 1985). Tay and Diener (2011, p. 363) in their empirical analysis of needs and subjective well-being (SWB) across a sample of 123 countries concluded that, "people need to fulfill a variety of needs, it is likely that a mix of daily activities that includes mastery, social relationships, and the meeting of physical needs is required for optimal SWB." Wankel (1993) suggested that an emphasis on enjoyment of LTPA (leisure-time physical activity) may have significant positive outcomes in two ways. One is its importance to leisure-time physical activity adherence and the second is through countering stress and facilitating positive psychological health. When sport ceases to be enjoyable, it is likely to cease to be a leisure choice. It is my contention that having high levels of sporting capital is fundamentally linked to the enhanced capacity for sport to be enjoyable and that achieving high levels of sporting capital is within the reach of most if not all individuals in developed societies. Achieving high levels of capital including human, social, cultural and sporting capital enhances the capacity for individuals to 'thrive' through self actualisation (Maslow, 1954), enhanced well-being and improved quality of life. It is linked to a philosophy of empowerment. Taking part in sport is always going to be a leisure choice, but it should be a choice made from a position of strength and capacity and not a negative one framed by limitation whether physical, psychological or social. 


\section{Structure of the book}

\section{Chapter 2. The public policy challenge for community sport: the need for a theoretically driven paradigm shift}

This chapter sets up the central contention of the book that sports development, both as a profession and as a wider field of public policy, has lacked a coherent theoretical foundation for its work. It argues that having a more coherent and robust theory to underpin sports development policy and practice is not just a nice to have discourse for academic debate but a fundamental prerequisite for effective public policy. In setting up this argument the chapter includes a broad overview of the challenges that public policy ambitions for sport have faced since the Great Britain Sports Council was established in the early 1970s to the present day post London Olympic legacy concerns with sedentary behaviours and increasing levels of obesity. The argument is made that despite large amounts of public investment we have failed to 'shift the curve' of participation in sport in England or make significant inroads into structural inequalities. The chapter concludes by introducing the reader to the sporting capital conceptual model and proposing that 'sporting capital' offers a new lens on sport behaviours and their determinants that the author believes has the potential to unlock the door to improved understanding and in turn more effective public policy intervention that could transform the sporting landscape in England. The universal nature of sporting capital suggests that it could equally be applied to sports development policy and practice in other developed countries, albeit contextualised by their differing socio-economic, political and cultural contexts.

\section{Chapter 3. Sporting capital - what is it, how does it relate to other forms of human, cultural and social capital and why is it important?}

This chapter provides a detailed explanation of the theoretical construct of 'sporting capital' as " the stock of physiological, social and psychological attributes and competencies that support and motivate an individual to participate in sport and to sustain that participation over time" (Rowe, 2015, p 45). It explains how sporting capital theory is distinctive from, but related to, theories concerning human, cultural and social capital and explores the qualities that make them transferable. The model of sporting capital with its three domains of the physiological, psychological and social are explained and the theoretical propositions that underpin it are elaborated. The central contention that higher levels of sporting capital will predict both current and future participation probabilities is introduced. The proposition is made that people with high levels of sporting 
capital are much more likely to engage in lifelong participation than their peers with low levels of sporting capital. Other important characteristics of sporting capital that relate to public policy are introduced to include the relationship between sporting capital and barriers and constraints to participation and its relationship to health outcomes, volunteering and transferable skills.

\section{Chapter 4. Theories of sport development and behaviour change - why do we need yet another theory?}

This chapter addresses the potential challenge that rather than lacking a sound theoretical foundation, although invariably not made explicit, sports development policy and practice has over the years been influenced by a number of theoretical constructs. A brief review of each of these theories concludes that their application to the public policy domain of community sports development is a not a perfect fit. The 'sport theories' are orientated towards elite sport success and associated talent identification, development and pathways and say little about the determinants and influences that lead to inactivity, drop out from sport at an early age or a failure to sustain sporting activity through the life-course. The theories borrowed from the wider health and physical activity public policy domains have their strength in being grounded in the fundamental drivers and determinants of behaviour change but lack the cultural and institutional specificity that distinguishes sport from informal exercise and activity in everyday life. The chapter concludes that an effective theory of sporting behaviour and its determinants must embed the very nature of sport as a synthesis of the physiological, psychological and social realities that shape an individual's sporting behaviours within the cultural context in which they live. It argues that sporting capital does this by addressing the sport specific factors that are influential in both the decision to participate in sport at any given time and most importantly the likelihood of sustaining that participation over time.

\section{Chapter 5. Sport participation over the life-course: linking the evidence to sporting capital theory}

In this chapter I review the evidence on determinants of participation in sport across the life-course through the lens of sporting capital theory. In doing so I 'sense check' the theory and point towards the implications for policy and practice that flow from the new perspective it provides. This chapter takes the propositions that flow from the theory of sporting capital and explores the evidence that is relevant to those propositions. Central to the idea of sporting capital is the proposition that having more or less of it impacts not just on an individual's current probability of playing sport but also on the likely future prospects of sustaining participation into middle 
and older age. The orientation of this chapter is, therefore, to take a lifecourse approach to participation in sport, starting with what we know about the determinants of sport (and physical activity) in the very young, and reviewing the evidence of how early experiences impact on and track through into adulthood. The chapter includes sections on: 'sport through the life-course'; 'the early socialisation process - starting young'; 'the early learning motivational climate'; 'the importance of fundamental movement skills'; 'the importance of interpersonal relationships - socialisation beyond the family'; 'barriers and constraints - the context for participation'; and 'an ageing population - sport participation into older age'.

\section{Chapter 6. Sporting capital in England: from measurement process to painting the landscape}

This chapter explains the challenges involved in 'pinning down sporting capital' into a set of quantifiable measures. It explains how the theory was translated into an empirical model built and tested using primary survey data collected in Sport England's large-scale population-wide Active People Survey. The reader is introduced to a 10-point 'Sporting Capital Index' and the modelled relationship between sporting capital and participation rates in sport are demonstrated. Summary statistics are presented to provide a 'landscape' overview on the levels and distribution of sporting capital in England and the importance of the findings for policy and practice are highlighted.

\section{Chapter 7. Sporting capital in England: understanding the impact of age, class, gender and sporting preferences}

This chapter explores in more depth the distribution of sporting capital across different groups in the population, variations in the building blocks of sporting capital and the implication for levels of sustained participation in sport. It shows that there are structural variations in the levels of sporting capital that in turn explain variations in participation rates and raise broader concerns about the challenges involved for public policy. The second part of the chapter examines how people's frequency of participation in sport and the types of sports they are likely to participate in are affected by their levels of sporting capital. It shows how sports that are more competitive, technically demanding and requiring greater organisation are likely to be attractive to those with high levels of sporting capital but less so for those with low levels. A different sporting capital profile for 'fitness-related sports' shows them to offer a greater appeal as an entry into sport for those with low levels of sporting capital. The implications for the roles of national governing bodies of sport and for public policy more generally are discussed. 


\section{Chapter 8. Building sporting capital: applying the theory to policy and practice}

This chapter takes the preceding theoretical and empirical discussion and explores the implications for policy and practice. At a macro level it explores the ingredients that might make up a national sport strategy that applies and structures its approach around the core theoretical constructs of sporting capital. This includes recommendations for the roles and responsibilities of the key agencies that impact on community sport outcomes and the implications for the 'agents of change' in the paid and voluntary workforce. At the micro level of project design and intervention it examines what this would look like if sporting capital 'principles' were applied and makes practical suggestions to help guide those in the front line of sports development. A brief exploration is made of the relevance and potential broader public policy application of sporting capital and its links through the transferability of capitals to wider social and health outcomes.

\section{Chapter 9. Where do we go from here? Applying, refining and testing the model of sporting capital}

Although acknowledged to be in its infancy, it is argued that sporting capital theory is plausible both in its internal logic and in its parallels with other well-established theories and concepts of human, cultural and social capital. Large claims are made for the potential impact sporting capital theory can have on public policy outcomes for sport. Initial empirical analysis has provided results that are promising and consistent with our broader understanding of the social profile of sport and the nature of differing sporting experiences. However, it is acknowledged that to become accepted as mainstream thinking to underpin public policy the theory requires to be systematically challenged, tested and refined through research. This chapter sets out a research agenda to include specific recommendations for 'strategic' research and for a programme of sporting capital-led interventionbased evaluative research to test and refine the theory in different settings to establish what works for whom and in what context. These settings could include comparative international research that might yield fascinating insights and explanations for the variability of sports participation across different countries. If successfully applied, sporting capital could become a universal language of sports development and the foundation for achieving our shared ambitions for sport in society.

\section{References}

Armour, K. ed., 2013. Sport pedagogy: An introduction for teaching and coaching. 2nd ed. London: Routledge. 
Bailey, R., Collins, D., Ford, P., MacNamara, A., Toms, M. and Pearce, G., 2010. Participant development in sport: An academic review. Leeds: Sports Coach UK.

Biddle, S. J. H. and Mutrie, N., 2008. Psychology of physical activity: Determinants, well-being and interventions. 2nd ed. London: Routledge.

Coalter, F., 1997. Leisure sciences and leisure studies: Different concept, same crisis? Leisure Sciences, 19(4), pp. 255-268. http://dx.doi.org/10.1080/01490409709512254

Coalter, F., 2007a. Sports clubs, social capital and social regeneration: 'Ill-defined interventions with hard to follow outcomes'? Sport in Society, 10(4), pp. 537-559.

Coalter, F., 2007b. A wider social role for sport: Who's keeping the score. London: Routledge.

Coalter, F., Long, J. and Duffield, B., 1988. Recreational welfare: The rationale for public sector investment in leisure. Aldershot: Gower/Avebury.

Collins, M. ed., 2010a. Examining sports development. London: Routledge.

Collins, M., 2010b. From 'sport for good' to 'sport for sport's sake' - not a good move for sports development in England? International Journal of Sport Policy, 2(3), pp. 367-379.

Council of Europe, 1992. European sports charter. R (92) 13 Rev. Strasbourg: Council of Europe.

Department for Culture, Media and Sport and the Strategy Unit, 2002. Game plan: A strategy for delivering government's sport and physical activity objectives. London: Cabinet Office.

Giulianotti, R., 2005. Sport, a critical sociology. Cambridge: Polity Press.

Gratton, C. and Henry, I. P. eds., 2001. Sport in the city: The role of sport in economic and social regeneration. London: Routledge.

Grix, J., 2016. Sport politics: An introduction. London: Palgrave.

Grix, J. and Carmichael, F., 2012. Why do governments invest in elite sport? A polemic. International Journal of Sport Policy and Politics, 4(1), pp. 73-90.

Grix, J. and Phillpots, L. eds., 2014. Understanding UK sport policy in context. London: Routledge.

Hallmann, K. and Petry, K. eds., 2013. Comparative sport development: Systems, participation and public policy. New York: Springer.

Henderson, K. A., 2009. A paradox of sport management and physical activity interventions. Sport Management Review, 12(2), pp. 57-65.

H. M. Government, 2015. Sporting future: A new strategy for an active nation. London: Cabinet Office.

Hoekman, R., Breedveld, K. and Scheerder, J., 2011. Introduction to the Special Issue on Sports participation in Europe. European Journal for Sport and Society, 8(1-2) pp. 7-13.

Houlihan, B., 1997. Sport, policy and politics: A comparative analysis. London: Routledge.

Houlihan, B., 2011. England. In: M. Nicholson, R. Hoye, and B. Houlihan, eds. Participation in sport, international policy perspectives. London: Routledge. pp. 10-24.

Houlihan, B., 2014. The government and politics of sport. 2nd ed. London: Routledge.

Houlihan, B. and Green, M. eds., 2011. Routledge handbook of sports development. London: Routledge.

Houlihan, B. and Lindsey, I., 2014. Sport policy in Britain. London: Routledge. 
Houlihan, B. and White, A., 2002. The politics of sport development: Development of sport or development through sport? London: Routledge.

Hylton, K. ed., 2013. Sport development: Policy, process and practice. 3rd ed. London: Routledge.

Hylton, K. and Totten, M., 2008. Community sports development. In: K. Hylton and P. Bramham, eds. Sports development: Policy, process and practice. New York: Routledge, pp. 77-117.

Jarvie, G. and Thornton, J., 2012. Sport, culture and society: An introduction. 2nd ed. London: Routledge.

Khan, K., Thompson, A., Blair, S., Sallis, J., Powell, K., Bull, F. and Bauman, A., 2012. Sport and exercise as contributors to the health of nations. The Lancet, 380(9836), pp. 59-64.

Kirk, D., Macdonald, D. and O'Sullivan, M., 2006. The handbook of physical education. London: Sage.

Long, J., Hylton, K., Spracklen, K., Ratna, A. and Bailey, S., 2009. Systematic review of the literature on black and minority ethnic communities in sport and physical recreation. London: Sport England.

Maguire, J., Jarvie, G., Mansfield, L. and Bradley, J. eds., 2002. Sport worlds: A sociological perspective. Champaign, IL: Human Kinetics.

Maslow, A. H., 1954. Motivation and personality. New York: Harper \& Row.

Nicholson, M., Hoye, R. and Houlihan, B. eds., 2011. Participation in sport: International perspectives. London: Routledge.

Rowe, N. F., 2015. Sporting capital: A theoretical and empirical analysis of sport participation determinants and its application to sports development policy and practice. International Journal of Sport Policy and Politics, 7(1), pp. 43-61.

Sallis, J. F., Owen, N. and Fisher, E. B., 2008. Ecological models of health behavior. In: K. Glanz, B. K. Rimer, and K. Viswanath, eds., Health behavior and health education: Theory, research and practice. San Francisco: Jossey-Bassan, pp. 465-486.

Sport England, 2004. The framework for sport in England. London: Sport England. Sport England, 2008. Sport England strategy 2008-11. London: Sport England.

Sport England, 2016. Sport England: Towards an active nation, strategy 2016-2021. London: Sport England.

Stuij, M., 2015. Habitus and social class: A case study on socialisation into sports and exercise. Sport, Education and Society, 20(6), pp. 780-798. http://dx.doi.org /10.1080/13573322.2013.827568

Tay, L. and Diener, E., 2011. Needs and subjective well-being around the world. Journal of Personality and Social Psychology, 101(2), pp. 354-365. http://dx.doi. org/10.1037/a0023779

Tinning, R., 2008. Pedagogy, sport pedagogy, and the field of kinesiology. Quest, 60(3), pp. 405-424.

UK Sport, 1999. COMPASS: Sport participation in Europe. London: UK Sport.

Van Bottenburg, M. and De Bosscher, V., 2011. An assessment of the impact of sports development on sports participation. In: B. Houlihan and M. Green, eds. Routledge handbook of sports development. London: Routledge. pp. 599-614

Van Bottenburg, M., Rijnen, B. and Sterkenburg, J. van, 2005. Sports participation in the European Union: Trends and differences. Nieuwegein, Netherlands: ARKO Sports Media. 
Wankel, L. M., 1993. The importance of enjoyment to adherence and psychological benefits from physical activity. International Journal of Sport Psychology, 24(2), pp. 151-169.

Wankel, L. M. and Kreisel, P. S. J., 1985. Factors underlying enjoyment of youth sports: Sport and age group comparisons. Journal of Sport Psychology, 7(1), pp. 51-64.

Weinberg, R. S. and Gould, D., 2015. Foundations of sport and exercise psychology. 6th ed. Champagne, IL: Human Kinetics. 


\section{Introduction}

Armour, K. ed. , 2013. Sport pedagogy: An introduction for teaching and coaching. 2nd ed. London: Routledge.

Bailey, R. , Collins, D. , Ford, P. , MacNamara, A. , Toms, M. and Pearce, G. , 2010. Participant development in sport: An academic review. Leeds: Sports Coach UK.

Biddle, S. J. H. and Mutrie, N. , 2008. Psychology of physical activity: Determinants, well-being and interventions. 2nd ed. London: Routledge.

Coalter, F. , 1997. Leisure sciences and leisure studies: Different concept, same crisis? Leisure Sciences, 19(4), pp. 255-268. http://dx.doi.org/10.1080/01490409709512254

Coalter, F. , 2007a. Sports clubs, social capital and social regeneration: 'Ill-defined interventions with hard to follow outcomes'? Sport in Society, 10(4), pp. 537-559.

Coalter, F. , 2007b. A wider social role for sport: Who's keeping the score. London: Routledge.

Coalter, F. , Long, J. and Duffield, B. , 1988. Recreational welfare: The rationale for public sector investment in leisure. Aldershot: Gower/Avebury.

Collins, M. ed. , 2010a. Examining sports development. London: Routledge.

Collins, M. , 2010b. From 'sport for good' to 'sport for sport's sake' - not a good move for sports development in England? International Journal of Sport Policy, 2(3), pp. 367-379.

Council of Europe , 1992. European sports charter. R (92) 13 Rev. Strasbourg: Council of Europe.

Department for Culture, Media and Sport and the Strategy Unit, 2002. Game plan: A strategy for delivering government's sport and physical activity objectives. London: Cabinet Office.

Giulianotti, R. , 2005. Sport, a critical sociology. Cambridge: Polity Press.

Gratton, C. and Henry, I. P. eds., 2001. Sport in the city: The role of sport in economic and social regeneration. London: Routledge.

Grix, J. , 2016. Sport politics: An introduction. London: Palgrave.

Grix, J. and Carmichael, F. , 2012. Why do governments invest in elite sport? A polemic.

International Journal of Sport Policy and Politics, 4(1), pp. 73-90.

Grix, J. and Phillpots, L. eds., 2014. Understanding UK sport policy in context. London:

Routledge.

Hallmann, K. and Petry, K. eds., 2013. Comparative sport development: Systems, participation and public policy. New York: Springer.

Henderson, K. A. , 2009. A paradox of sport management and physical activity interventions.

Sport Management Review, 12(2), pp. 57-65.

H. M. Government , 2015. Sporting future: A new strategy for an active nation. London: Cabinet Office.

Hoekman, R. , Breedveld, K. and Scheerder, J. , 2011. Introduction to the Special Issue on Sports participation in Europe. European Journal for Sport and Society, 8(1-2) pp. 7-13.

Houlihan, B. , 1997. Sport, policy and politics: A comparative analysis. London: Routledge.

Houlihan, B. , 2011. England. In: M. Nicholson, R. Hoye, and B. Houlihan, eds. Participation in sport, international policy perspectives. London: Routledge. pp. 10-24.

Houlihan, B. , 2014. The government and politics of sport. 2nd ed. London: Routledge.

Houlihan, B. and Green, M. eds., 2011. Routledge handbook of sports development. London:

Routledge.

Houlihan, B. and Lindsey, I. , 2014. Sport policy in Britain. London: Routledge.

Houlihan, B. and White, A. , 2002. The politics of sport development: Development of sport or development through sport London: Routledge.

Hylton, K. ed., 2013. Sport development: Policy, process and practice. 3rd ed. London:

Routledge.

Hylton, K. and Totten, M. , 2008. Community sports development. In: K. Hylton and P. Bramham , eds. Sports development: Policy, process and practice. New York: Routledge, pp. 77-117.

Jarvie, G. and Thornton, J. , 2012. Sport, culture and society: An introduction. 2nd ed. London: Routledge.

Khan, K. , Thompson, A. , Blair, S. , Sallis, J. , Powell, K. , Bull, F. and Bauman, A. , 2012. Sport and exercise as contributors to the health of nations. The Lancet, 380(9836), pp. 59-64.

Kirk, D. , Macdonald, D. and O'Sullivan, M. , 2006. The handbook of physical education. London: Sage. 
Long, J. , Hylton, K. , Spracklen, K. , Ratna, A. and Bailey, S. , 2009. Systematic review of the literature on black and minority ethnic communities in sport and physical recreation. London: Sport England.

Maguire, J. , Jarvie, G. , Mansfield, L. and Bradley, J. eds., 2002. Sport worlds: A sociological perspective. Champaign, IL: Human Kinetics.

Maslow, A. H. , 1954. Motivation and personality. New York: Harper \& Row.

Nicholson, M. , Hoye, R. and Houlihan, B. eds., 2011. Participation in sport: International perspectives. London: Routledge.

Rowe, N. F. , 2015. Sporting capital: A theoretical and empirical analysis of sport participation determinants and its application to sports development policy and practice. International Journal of Sport Policy and Politics, 7(1), pp. 43-61.

Sallis, J. F. , Owen, N. and Fisher, E. B. , 2008. Ecological models of health behavior. In: K. Glanz , B. K. Rimer , and K. Viswanath , eds., Health behavior and health education: Theory, research and practice. San Francisco: Jossey-Bassan, pp. 465-486.

Sport England , 2004. The framework for sport in England. London: Sport England.

Sport England , 2008. Sport England strategy 2008-11. London: Sport England.

Sport England, 2016. Sport England: Towards an active nation, strategy 2016-2021. London:

Sport England.

Stuij, M. , 2015. Habitus and social class: A case study on socialisation into sports and exercise. Sport, Education and Society, 20(6), pp. 780-798.

http://dx.doi.org/10.1080/13573322.2013.827568

Tay, L. and Diener, E. , 2011. Needs and subjective well-being around the world. Journal of Personality and Social Psychology, 101(2), pp. 354-365. http://dx.doi.org/10.1037/a0023779 Tinning, R. , 2008. Pedagogy, sport pedagogy, and the field of kinesiology. Quest, 60(3), pp. 405-424.

UK Sport , 1999. COMPASS: Sport participation in Europe. London: UK Sport. Van Bottenburg, M. and De Bosscher, V. , 2011. An assessment of the impact of sports development on sports participation. In: B. Houlihan and M. Green, eds. Routledge handbook of sports development. London: Routledge. pp. 599-614

Van Bottenburg, M. , Rijnen, B. and Sterkenburg, J. van , 2005. Sports participation in the European Union: Trends and differences. Nieuwegein, Netherlands: ARKO Sports Media. Wankel, L. M. , 1993. The importance of enjoyment to adherence and psychological benefits from physical activity. International Journal of Sport Psychology, 24(2), pp. 151-169.

Wankel, L. M. and Kreisel, P. S. J. , 1985. Factors underlying enjoyment of youth sports: Sport and age group comparisons. Journal of Sport Psychology, 7(1), pp. 51-64.

Weinberg, R. S. and Gould, D. , 2015. Foundations of sport and exercise psychology. 6th ed. Champagne, IL: Human Kinetics.

\section{The public policy challenge for community sport}

Bretherton, P. , Piggin, J. and Bodet, G. , 2016. Olympic sport and physical activity promotion: The rise and fall of the London 2012 pre-event mass participation 'legacy'. International Journal of Sport Policy and Politics, 8(4), pp. 609-624.

http://dx.doi.org/10.1080/19406940.2016.1229686

Bullough, S. J. , 2012. A new look at the latent demand for sport and its potential to deliver a positive legacy for London 2012. International Journal of Sport Policy and Politics, 4(1), pp.

39-54. http://dx.doi.org/10.1080/19406940.2011.627357

Cavill, N. , Kahlmeier, S. and Racioppi, F. , 2006. Physical activity and health in Europe:

Evidence for action. Copenhagen: World Health Organisation.

Central Council of Physical Recreation Great Britain , 1960. Sport \& the community: The report of the Wolfenden Committee on Sport (Chairman, Sir John Wolfenden ). London: HMSO.

Coalter, F. , 2007. A wider social role for sport: Who's keeping the score. London: Routledge.

Coalter, F. , 2013. Game plan and the spirit level: The class ceiling and the limits of sports

policy? International Journal of Sport Policy and Politics, 5(1), pp. 3-19.

http://dx.doi.org/10.1080/19406940.2012.656690 
Coalter, F. , Dowers, S. and Baxter, M. , 1995. The impact of social class and education on sports participation: Some evidence from the general household survey. In: K. Roberts, ed. Leisure and social stratification. Brighton: Leisure Studies Association.

Collins, M. , 2010. From 'sport for good' to 'sport for sport's sake' - not a good move for sports development in England? International Journal of Sport Policy, 2(3), pp. 367-379.

Conklin, J. , Basadur, M. and Van Patter, G. , 2007. Rethinking wicked problems: Unpacking paradigms, bridging universes: Interview. NextD Journal, (10), pp. 1-30, Conversation 10.1. Curry, A. and Stanier, R. , 2003. Strategic framework for community sport in England: Meeting the challenge of game plan: Emerging insights on the future of participation in sport in England. An Interim Report to Sport England. Reading: The Henley Centre.

Department for Culture, Media and Sport , 2008. Before, during and after: Making the most of the London 2012 Games. London: DCMS.

Department for Culture, Media and Sport , 2012. Creating a sporting habit for life: A new youth sport strategy. London: DCMS.

Department for Culture, Media and Sport , 2016. National lottery grants search: Grants awarded by distributing body [online]. Available at:

$<$ www.lottery.culture.gov.uk/GrantsByDistributingBody.aspx> [accessed 6th December 2016]. Department for Culture, Media and Sport and the Strategy Unit, 2002. Game plan: A strategy for delivering government's sport and physical activity objectives. London: Cabinet Office.

Department of Health , 2011. Start active, stay active: A report on physical activity from the four home countries' Chief Medical Officers. London: The Stationery Office Limited.

Eurostat , 2014. Sport and physical activity report. Special Eurobarometer 412. Brussels: European Commission.

Gratton, C. , Rowe, N. and Veal, A. J. , 2011. International Comparisons of Sports participation in European Countries: an Update of the COMPASS Project. European Journal for Sport and Society, 8(1/2), pp 99-116

Grix, J. and Carmichael, F. , 2012. Why do governments invest in elite sport? A polemic. International Journal of Sport Policy and Politics, 4(1), pp. 73-90.

H. M. Government , 2015. Sporting future: A new strategy for an active nation. London: Cabinet Office.

Houlihan, B. , 2011. England. In: M. Nicholson, H. Hoye, and B. Houlihan, eds. Participation in sport, international policy perspectives. London: Routledge, pp. 10-24.

Houlihan, B. and White, A. , 2002. The politics of sport development: Development of sport or development through sport? London: Routledge.

Nicholson, M. , Hoye, R. and Houlihan, B. eds., 2011. Participation in sport: International perspectives. London: Routledge.

Public Health England , 2014. Everybody active, every day: An evidence-based approach to physical activity. London: Public Health England.

Rittel, H. W. J. and Webber, M. M. , 1973. Dilemmas in a general theory of planning. Policy Sciences, 4(2), pp. 155-169.

Rowe, N. F. , 2002. Sports equity index for regular participation. London: Sport England.

Rowe, N. F. ed., 2004. Driving up participation: The challenge for sport. London: Sport England. Rowe, N. F. , 2009. The active people survey: A catalyst for transforming evidence-based sport policy in England. International Journal of Sport Policy and Politics, 1(1), pp. 89-98.

http://dx.doi.org/10.1080/19406940802681244

Rowe, N. F. , 2015. Sporting capital: A theoretical and empirical analysis of sport participation determinants and its application to sports development policy and practice. International Journal of Sport Policy and Politics, 7(1), pp. 43-61.

Rowe, N. F. , Adams, R. and Beasley, N. , 2004. Driving up participation in sport: The social context, the trends, the prospects and the challenges. In: N. F. Rowe, ed. Driving up

participation: The challenge for sport. London: Sport England, pp. 6-13.

Rowe, N. F. and Moore, S. , 2001. Participation in sport: Past trends and future prospects. London: UK Sport and Sport England.

Scheerder, J. , Vandermeerschen, H. , Van Tuyckom, C. , Hoekman, R. , Breedveld, K. and Vos, S. , 2011. Understanding the game, sport participation in Europe, facts, reflections and recommendations. Sport Policy and Management Report 10. Leuven, Belgium: Research Unit of Social Kinesiology and Sport Management of the K. U. Leuven. 
Scheerder, J. , Vanreusel, B. , Taks, M. and Renson, R. , 2002. Social sports stratification in Flanders 1969-1999: Intergenerational reproduction of social inequalities? International Review for the Sociology of Sport, 37(2), pp. 219-245.

http://dx.doi.org/10.1177/1012690202037002006.

Sport England , 1999. Survey of sports halls and swimming pools in England. London: Sport England.

Sport England , 2000. Performance measurement for local authority sports halls and swimming pools. London: Sport England.

Sport England , 2004. The framework for sport in England. London: Sport England.

Sport England , 2008. Sport England strategy 2008-11. London: Sport England.

Sport England , 2013. Active people interactive [online]. Available at: <http://active-

people.sportengland.org > [accessed 13th December 2016].

Sport England, 2016. Sport England: Towards an active nation, strategy 2016-2021. London:

Sport England.

UK Sport , 1999. COMPASS: Sport participation in Europe. London: UK Sport.

Van Bottenburg, M. and De Bosscher, V. , 2011. An assessment of the impact of sports

development on sports participation. In: B. Houlihan and M. Green, eds. Routledge handbook of sports development. London: Routledge. pp. 599-614.

Van Bottenburg, M. , Rijnen, B. and Sterkenburg, J. van , 2005. Sports participation in the European Union: Trends and differences. Nieuwegein, Netherlands: Arko Sports Media.

Van Tuyckom, C. , Scheerder, J. and Bracke, P. , 2010. Gender and age inequalities in regular sports participation: A crossnational study of 25 European countries. Journal of Sports

Sciences, 28(10), pp. 1077-1084. http://dx.doi.org/10.1080/02640414.2010.492229

Weed, M. , 2013. London 2012 legacy strategy: Ambitions, promises and implementation plans. In: V. Girginov , ed. Handbook of the London 2012 Olympic and Paralympic Games (Volume One). Great Britain: Routledge, pp. 87-98.

Weed, M. , 2016. Should we privilege sport for health? The comparative effectiveness of UK government investment in sport as a public health intervention. International Journal of Sport Policy and Politics, 8(4), pp. 559-576.

Weed, M. , Coren, E. , Fiore, J. , Wellard, I. , Chatziefstathiou, D. , Mansfield, L. and Dowse, S. , 2015. The Olympic Games and raising sport participation: A systematic review of evidence and an interrogation of policy for a demonstration effect. European Sport Management Quarterly, 15(2), pp. 195-226. http://dx.doi.org/10.1080/16184742.2014.998695

Weiss, C. H. , 1993. Where politics and evaluation research meet. Evaluation Practice, 14(1), pp. 93-106.

Wilson, R. and Pickett, K. , 2009. The spirit level: Why more equal societies almost always do better. London: Allen Lane.

Wood, L. and Danylchuk, K. , 2015. The impact of constraints and negotiation strategies on involvement in intramural sport. Managing Sport \& Leisure, 20(3), pp. 157-173.

\section{Sporting capital - what is it, how does it relate to other forms of human, cultural and social capital and why is it important?}

Bakera, J. and Horton, S. , 2004. A review of primary and secondary influences on sport expertise. High Ability Studies, 15(2), pp. 211-228.

http://dx.doi.org/10.1080/1359813042000314781

BBC , 2010. Cameron and Clegg set out 'big society' policy ideas. Available at:

<http://news.bbc.co.uk/1/hi/uk_politics/8688860.stm> [accessed 9th January 2017].

Becker, G. , 1964. Human capital: A theoretical and empirical analysis, with special reference to education. New York: National Bureau of Economic Research; Distributed by Columbia University Press.

Bourdieu, P. , 1986. The forms of capital. In: J. Richardson, ed. Handbook of theory and research for the sociology of education. New York: Greenwood, pp. 241-258.

The Cabinet Office , 2010. Building the big society. Available at:

$<w w w . c a b i n e t o f f i c e . g o v . u k / c o n t e n t / b i g-s o c i e t y-o v e r v i e w>$. 
Coalter, F. , 2007. A wider social role for sport: Who's keeping the score. London: Routledge. Crawford, D. W. and Godbey, G. , 1987. Reconceptualizing barriers to family leisure. Leisure Sciences, 9(2), pp. 119-127.

Crawford, D. W. , Jackson, E. L. and Godbey, G. , 1991. A hierarchical model of leisure constraints. Leisure Sciences, 13(4), pp. 309-320.

Csikszentmihalyi, M. , 1978. Attention and the holistic approach to behaviour. In: K. S. Pope and J. L. Singer, eds. The stream of consciousness: Scientific investigations into the flow of human experience. New York: Plenum Publishing, pp. 335-385.

Csikszentmihalyi, M. , 1990. Flow: The psychology of optimal experience. New York: Harper \& Row.

Csikszentmihalyi, M. and Nakamura, J. , 1989. The dynamics of intrinsic motivation: A study of adolescents. In: C. Ames and R. Ames, eds. Research on motivation in education, vol. 3: Goals and cognitions. New York: Academic Press, pp. 45-71.

De Graaf, N. D. , De Graaf, P. M. and Kraaykamp, G. , 2000. Parental cultural capital and educational attainment in the Netherlands: A refinement of the cultural capital perspective. Sociology of Education, 73(2), pp. 92-111.

Driscoll, K. and Wood, L. , 1999. Sporting capital: Changes and challenges for rural communities in Victoria. Melbourne: Centre for Applied Social Research, RMIT.

Duckworth, A. L. , Peterson, C. , Matthews, M. D. and Kelly, D. R. , 2007. Grit: Perseverance and passion for long - term goals. Journal of Personality and Social Psychology, 92(6), pp. 1087-1101.

Eurostat , 2014. Sport and physical activity report. Special Eurobarometer 412. Brussels: European Commission.

Fisher, K. , 2002. Chewing the fat: The story time diaries tell about physical activity in the United Kingdom. Working Papers of the Institute for Social and Economic Research, Paper 2002-2013. Colchester: University of Essex.

Gershuny, J. , 2003. Time, through the lifecourse, in the family. ISER Working Paper 2003-3; Colchester: University of Essex.

Goldthorpe, J. H. , undated. Cultural capital: Some critical observations. Sociology Working Papers Paper Number 2007-2007. Oxford: Department of Sociology University of Oxford. Available at: <www.sociology.ox.ac.uk/materials/papers/swp07_07.pdf> [accessed 4th January 2017].

Halsey, A. H. , Heath, A. F. and Ridge, J. M. , 1980. Origins and destinations. Oxford: Clarendon Press.

Haworth, J. , 1993. Skills-challenge relationships and psychological well-being in everyday life. Society \& Leisure, 16(1), pp. 115-128.

Jackson, E. L. , Crawford, D. W. and Godbey, G. , 1993. Negotiation of leisure constraints. Leisure Sciences, 15(1), pp. 1-11.

Jackson, S. A. , Kimiecik, J. C. , Ford, S. and Marsh, H. W. , 1998. Psychological correlates of flow in sport. Journal of Sport \& Exercise Psychology, 20(4), pp. 358-378.

Matthews, P. , Xu, D. , Matusiak, M. and Prior, G. , 2016. Taking part: Findings from the longitudinal survey waves 1 to 3. April. TNS BMRB. London: Department for Culture Media and Sport.

Nakamura, J. and Csikszentmihalyi, M. , 2005. The concept of flow. In: C. R. Snyder and S. J. Lopez, eds. Handbook of positive psychology. New York: Oxford University Press, pp. 89-105. Nicholson, M. and Hoye, R. eds., 2008. Sport and social capital. Oxford: ButterworthHeinemann.

Putnam, R. D. , 2000. Bowling alone: The collapse and revival of American community. New York: Simon and Schuster.

Rowe, N. F. , 2015. Sporting capital: A theoretical and empirical analysis of sport participation determinants and its application to sports development policy and practice. International Journal of Sport Policy and Politics, 7(1), pp. 43-61.

Shilling, C. , 1991. Educating the body: Physical capital and the production of social inequalities. Sociology, 25(4), pp. 653-672.

Shilling, C. , 1993. The body and social theory. London: Sage.

Stempel, C. , 2006. Gender, social class, and the sporting capital-economic capital nexus.

Sociology of Sport Journal, 23(3), pp. 273-292. 
Stuij, M. , 2015. Habitus and social class: A case study on socialisation into sports and exercise. Sport, Education and Society, 20(6), pp. 780-798.

http://dx.doi.org/10.1080/13573322.2013.827568

Tlili, A. and Obsiye, M. , 2014. What is Coleman's social capital the name of? A critique of a not very social capital. Critical Sociology, 40(4), pp. 551-574.

Warde, A. , 2006. Cultural capital and the place for sport. Cultural Trends, 15(2-3), pp.

107-122.

\section{Theories of sport development and behaviour change - why do we need yet another theory?}

Ajzen, I. , 1985. From intentions to actions: A theory of planned behavior. In: J. Kuhl and J.

Beckman, eds. Action-control: From cognition to behavior. New York: Springer, pp. 11-39.

Bailey, R. , 2007. Talent development and the luck problem. Sport, Ethics and Philosophy, 1(3), pp. 367-377. http://dx.doi.org/10.1080/17511320701676999

Bailey, R. , Collins, D. , Ford, P. , MacNamara, A. , Toms, M. and Pearce, G. , 2010. Participant development in sport: An academic review. Leeds: Sports Coach UK.

Bailey, R. and Morley, D. , 2006. Towards a model of talent development in physical education. Sport, Education and Society, 11(3), pp. 211-230.

http://dx.doi.org/10.1080/13573320600813366

Balyi, I. and Hamilton, A. , 2000. A key to success: Long-term athlete development. Sport

Coach (Canberra, Australia), 23(1), pp. 10-32.

Bandura, A. , 1986. Social foundations of thought and action, a social cognitive theory.

Englewood Cliffs, NJ: Prentice Hall.

Bandura, A. , 1998. Health promotion from the perspective of social cognitive theory.

Psychology and Health, 13(4), pp. 623-649.

Bandura, A. , 2001. Social cognitive theory: An agentic perspective. Annual Review of

Psychology, 52, pp. 1-26.

Benson, P. and Scales, P. , 2009. The definition and preliminary measurement of thriving in adolescence. The Journal of Positive Psychology, 4(1), pp. 85-104.

Côté, J. , 1999. The influence of the family in the development of talent in sport. Sport

Psychologist, 13(4), pp. 395-417.

Côté, J. and Fraser-Thomas, J. , 2007. Youth involvement in sport. In: P. Crocker, ed. Introduction to sport psychology: A Canadian perspective. Toronto: Pearson Prentice Hall, pp. 266-294.

Engel, G. L. , 1977. The need for a new medical model: A challenge for biomedicine. Science, 196(4286), pp. 129-136. http://dx.doi.org/10.1126/science.847460

Fishbein, M. and Azjen, I. , 1975. Belief, attitude, intention, behaviour: An introduction to the theory and research. Reading, MA: Addison-Wesley.

Foster, C. , Hillsdon, M. , Cavill, N. , Allender, S. and Cowburn, G. , 2005. Understanding participation in sport: A systematic review. London: Sport England.

Hausenblas, H. A. , Carron, A. V. and Mack, D. E. , 1997. Applications of the theories of reasoned action and planned behavior to exercise behavior, a meta-analysis. Journal of Sport \& Exercise Psychology, 19(1), pp. 36-51.

Houlihan, B. , 2000. Sporting excellence, schools and sports development: The politics of crowded policy spaces. European Physical Education Review, 6(2), pp. 171-193.

Houlihan, B. and White, A. , 2002. The politics of sport development: Development of sport or development through sport? London: Routledge.

King, A. C. , Stokols, D. , Talen, E. , Brassington, G. S. and Killingsworth, R. , 2002. Theoretical approaches to the promotion of physical activity: Forging a transdisciplinary paradigm.

American Journal of Preventive Medicine, 23(2S), pp. 15-25.

King, P. , Dowling, E. , Mueller, R. , White, K. , Schultz, W. , Osborn, P. , Dickerson, E. , Bobek, D. , Lerner, R. , Benson, P. and Scales, P. , 2005. Thriving in adolescence: The voices of youth serving practitioners, parents and early and late adolescents. Journal of Early Adolescence,

25(1), pp. 94-112. 
Kirk, D. and Gorely, T. , 2000. Challenging thinking about the relationship between school physical education and sport performance. European Physical Education, 6(2), pp. 119-134. Kohl, H. W. , Craig, C. L. , Lambert, E. V. , Inoue, S. , Alkandari, J. R. and Leetongin, G. , 2012. The pandemic of physical inactivity: Global action for public health. The Lancet, 380(9838), pp. 294-305. http://dx.doi.org/10.1016/S0140-6736(12)60898-8

Maslow, A. H. , 1954. Motivation and personality. New York: Harper \& Row.

Prochaska, J. O. , Diclemente, C. C. and Norcross, J. C. , 1992. In search of how people change: Applications to addictive behaviours. American Psychologist, 47(9), pp. 1102-1114.

Prochaska, J. O. and Velicer, W. F. , 1997. The transtheoretical model of behavior change. American Journal of Health Promotion, 12(1), pp. 38-48.

Rittel, H. W. J. and Webber, M. M. , 1973. Dilemmas in a general theory of planning. Policy Sciences, 4(2), pp. 155-169.

Scheerder, J. , Vandermeerschen, H. , Van Tuyckom, C. , Hoekman, R. , Breedveld, K. and Vos, S. , 2011. Understanding the game: Sport participation in Europe: Facts, reflections and recommendations. Sports Policy and Management, 10. Leuven, Belgium: K.U. Leuven.

Scitovsky, T. , 1992. The joyless economy. The Psychology of Human Satisfaction. Revised edition first published 1976. New York, Oxford: Oxford University Press.

Sirgy, M. J. and Wu, J. , 2009. The pleasant life, the engaged life, and the meaningful lie: What about the balanced life? Journal of Happiness Studies, 10(2), pp. 183-196.

http://dx.doi.org/10.1007/s10902-007-9074-1

Tay, L. and Diener, E. , 2011. Needs and subjective well-being around the world. Journal of Personality and Social Psychology, 101(2), pp. 354-365.

United Nations , 1998. Human development report 1998. United Nations Development Programme. Oxford: Oxford University Press.

\section{Sport participation over the life-course}

Allender, S. , Hutchinson, L. and Foster, C. , 2008. Life-change events and participation in physical activity: A systematic review. Health Promotion International, 23(2), pp. 160-172.

Apostolou, M. , 2015. The evolution of sports: Age-cohort effects in sports participation. International Journal of Sport and Exercise Psychology, 13(4), pp. 359-370.

http://dx.doi.org/10.1080/1612197X.2014.982678

Arkenford Ltd. , 2006. Understanding participation in sport: What determines sports participation among recently retired people? London: Sport England.

Bandura, A. , 1977. Social learning theory. Englewood Cliffs, NJ: Prentice-Hall.

Bandura, A. , 1997. Self-efficacy: The exercise of control. New York: W. H. Freeman.

Barnett, L. M. , van Beurden, E. , Morgan, P. J. , Brooks, L. O. and Beard, J. R. , 2010. Gender differences in motor skill proficiency from childhood to adolescence. Research Quarterly for Exercise and Sport, 81(2), pp. 162-170. http://dx.doi.org/10.1080/02701367.2010.10599663 Baxter-Jones, A. D. and Maffulli, N. , 2003. Parental influence on sport participation in elite young athletes. Journal of Sports Medicine and Physical Fitness, 43(2), pp. 250-255.

Bell, S. and Lee, C. , 2005. Emerging adulthood and patterns of physical activity among young Australian women. International Journal of Behavioral Medicine, 12(4), pp. 227-235.

Berlin, K. L. and Klenosky, D. B. , 2014. Let me play, not exercise! A laddering study of older women's motivations for continued engagement in sports-based versus exercise-based leisure time physical activities. Journal of Leisure Research, 46(2), pp. 127-152.

Biddle, S. J. H. , Atkin, A. J. , Cavill, N. and Foster, C. , 2011. Correlates of physical activity in youth: A review of quantitative systematic review. International Review of Sport and Exercise Psychology, 4(1), pp. 25-49. http://dx.doi.org/10.1080/1750984X.2010.548528

Biddle, S. J. H. , Coalter, F. , O'Donovan, T. , MacBeth, J. , Nevill, M. and Whitehead, S. , 2004 Increasing demand for sport and physical activity by girls. Edinburgh: Sport Scotland.

Biddle, S. J. H. , Cury, F. , Goudas, M. , Sarrazin, P. , Famose, J. P. and Durand, M. , 1995. Development of scales to measure perceived physical education class climate: A cross-national project. British Journal of Educational Psychology, 65(3), pp. 341-558. 
Biddle, S. J. H. , Wang, C. K. J. , Kavussanu, M. and Spray, C. M. , 2003. Correlates of achievement goal orientations in physical activity: A systematic review of research. European Journal of Sport Science, 3(5), pp. 1-20.

Biddle, S. J. H. , Whitehead, S. H. , O'Donovan, T. M. and Nevill, M. E. , 2005. Correlates of participation in physical activity of adolescent girls: A systematic review of recent literature. Journal of Physical Activity and Health, 2(4), pp. 423-434.

Birchwood, D. , Roberts, K. and Pollock, G. , 2008. Explaining differences in sport participation rates among young adults: Evidence from the South Caucasus. European Physical Education Review, 14(3), pp. 283-298.

Bourdieu, P. , 1984. Distinction: A social critique of the judgement of taste. Cambridge, MA: Harvard University Press.

Brudzynski, L. and Ebben, W. P. , 2010. Body image as a motivator and barrier to exercise participation. International Journal of Exercise Science, 3(1), pp. 14-24.

Brustad, R. J. , 1992. Integrating socialization influences into the study of children's motivation in sport. Journal of Sport \& Exercise Psychology, 14(1), pp. 59-77.

Brustad, R. J. , 1993. Who will go out and play? Parental and psychological influences on children's attraction to physical activity. Pediatric Exercise Science, 5(3), pp. 210-223.

Bungum, T. , Dowda, M. , Weston, A. , Trost, S. G. and Pate, R. R. , 2000. Correlates of physical activity in male and female youth. Pediatric Exercise Science, 12(1), pp. 71-79. Burch, W. , 1969. Social circles of leisure: Competing explanations. Journal of Leisure Research, 41(3), pp. 125-147.

Carson, V. , 2016. Cross-sectional and longitudinal associations between parental support and children's physical activity in the early years. Journal of Physical Activity and Health, 13(6), pp. 611-616.

Casper, J. M. , Bocarro, J. N. , Kanters, M. A. and Floyd, M. F. , 2011. 'Just let me play!'-understanding constraints that limit adolescent sport participation. Journal of Physical Activity and Health, 8(Supplement 1), pp. S32-S39.

Coakley, J. and White, A. , 1992. Making decisions: Gender and sport participation among British adolescents. Sociology of Sport Journal, 9(1), pp. 20-35.

Coleman, L. , Cox, L. and Roker, D. , 2008. Girls and young women's participation in physical activity: Psychological and social influences. Health Education Research, 23(4), pp. 633-647. http://dx.doi.org/10.1093/her/cym040

Côté, J. , Horton, S. , MacDonald, D. and Wilkes, S. , 2009. The benefits of sampling sports during childhood. Physical and Health Education Journal, 74(4), pp. 6-11.

Cox, L. , Coleman, L. and Roker, D. , 2006. Understanding participation in sport: What determines sports participation among 15-19 year old women? Research Conducted by: Trust for the Study of Adolescence. London: Sport England.

Dagkas, S. and Stathi, A. , 2007. Exploring social and environmental factors affecting adolescents' participation in physical activity. European Physical Education Review, 13(3), pp. 369-384.

Deci, E. L. and Ryan, R. M. , 1985. Intrinsic motivation and self-determination in human behavior. New York: Plenum Publishing.

Dovey, S. M. , Reeder, A. I. and Chalmers, D. J. , 1998. Continuity and change in sporting and leisure time physical activities during adolescence. British Journal of Sports Medicine, 32(1), pp. 53-57. http://dx.doi.org/10.1136/bjsm.32.1.53

Duncan, J. M. , Al-Nakeeb, Y. , Nevill, A. and Jones, M. V. , 2004. Body image and physical activity in British secondary school children. European Physical Education Review, 10(3), pp. 243-260.

Duncan, M. , Woodfield, L. , Al-Nakeeb, Y. and Nevill, A. , 2002. The impact of socio-economic status on the physical activity levels of British secondary school children. European Journal of Physical Education, 7(1), pp. 30-44.

Eccles, J. , Barber, B. L. , Stone, M. and Hunt, J. , 2003. Extracurricular activities and adolescent development. Journal of Social Issues, 59(4), pp. 865-889.

Edwardson, C. L. and Gorely, T. , 2010. Parental influences on different types and intensities of physical activity in youth: A systematic review. Psychology of Sport and Exercise, 11(6), pp. 522-535.

Eurostat , 2014. Sport and physical activity report. Special Eurobarometer 412. Brussels: European Commission. 
Flintoff, A. and Scraton, S. , 2001. Stepping into active leisure? Young women's perceptions of active lifestyles and their experiences of school physical education. Sport, Education and Society, 6(1), pp. 5-21.

Fox, K. , 2000. Review of evidence on the impact of exercise on self esteem. In: S. Biddle, K. Fox, and S. Boutcher, eds. Physical activity and psychological well-being. London: Routledge, pp. 88-117.

Fraser-Thomas, J. and Côté, J. , 2009. Understanding adolescents' positive and negative developmental experiences in sport. The Sport Psychologist, 23, pp. 3-23.

Fraser-Thomas, J. , Côté, J. and Deakin, J. , 2005. Youth sport programs: An avenue to foster positive youth development. Physical Education and Sport Pedagogy, 10(1), pp. 19-40.

Garcia, A. W. and King, A. C. , 1991. Predicting long term adherence to aerobic exercise: A comparison of two models. Journal of Sport and Exercise Psychology, 13(4), pp. 394-410. Gershuny, J. , 2003. Time, through the lifecourse, in the family. ISER Working Paper 2003-3. Colchester: University of Essex.

Godbey, G. C. , 2005. Time as a constraint to leisure. In: E. L. Jackson, ed. Constraints to leisure. State College, PA: Venture Publishing, pp. 185-200.

Godin, G. and Shephard, R. J. , 1986. Psychological factors influencing intentions to exercise of young students from grades 7 to 9. Research Quarterly for Exercise and Sport, 57(1), pp. 41-52.

Goretzki, J. and Esser, A. , 2008. Project 'experience of sport' research debrief [online]. London: Henley Centre HeadlightVision. Available at https://www.sport-

england.org/media/3707/quality_of_sporting_experience.pdf

Grant, B. C. , 2001. 'You're never too old': Beliefs about physical activity and playing sport in later life. Ageing and Society, 21(6), pp. 777-798.

Greenwood-Parr, M. and Oslin, J. , 1998. Promoting lifelong involvement through physical activity. Journal of Physical Education, Recreation and Dance, 69(2), pp. 72-76.

Hagger, M. S. , Chatzisarantis, N. and Biddle, S.J.H. , 2001. The influence of self-efficacy and past behaviour on the physical activity intentions of young people. Journal of Sports Sciences, 19, pp. 711-725.

Hills, L. , 2007. Friendship, physicality, and physical education: An exploration of the social and embodied dynamics of girls' physical education experiences. Sport, Education and Society, 12(3), pp. 317-336.

Holt, N. L. and Jones, M. I. , 2008. Future directions for positive youth development and sport. In: N. L. Holt , ed. Positive youth development through sport. London: Routledge, pp. 122-132. Horn, D. B. , O'Neill, J. R. , Pfeiffer, K. A. , Dowda, M. and Pate, R. R. , 2008. Predictors of physical activity in the transition after high school among young women. Journal of Physical Activity and Health, 5(2), pp. 275-285.

Hume, C. , Salmon, J. and Ball, K. , 2005. Children's perceptions of their home and neighbourhood environments, and their association with objectively measured physical activity: a qualitative and quantitative study. Health Education Research, 20(1), pp. 1-13.

Khan, H. , 2013. 5 Hours a day: Systemic innovation for an ageing population. NESTA. Available at: <www.nesta.org.uk/sites/default/files/five_hours_a_day_jan13.pdf $>$.

Kirk, D. , 2004. Sport and early learning experiences. In: N. Rowe, ed. Driving up participation: The challenge for sport. London: Sport England, pp. 67-76.

Kirk, D. , 2005. Physical education, youth sport and lifelong participation: The importance of early learning experiences. European Physical Education Review, 11(3), pp. 239-255.

Kirkwood, T. , 2006. Ageing: Too fast by mistake. Nature, 444(7122), pp. 1015-1016. Kyle, G. , Absher, J. , Norman, W. , Hammitt, W. and Jodice, L. , 2007. A modified involvement scale. Leisure Studies, 26(4), pp. 399-427. http://dx.doi.org/10.1080/02614360600896668 Kyle, G. and Chick, G. , 2004. Enduring leisure involvement: The importance of personal relationships. Leisure Studies, 23(3), pp. 243-266.

Lewko, J. H. and Greendorfer, S. L. , 1978. Family influences and sex differences in children's socialization into sport: A review. In: D. M. Landers and R. W. Christina, eds. Psychology of motor behaviour and sport. Champaign, IL: Human Kinetics, pp. 287-300.

Long, J. , 2004. Sport and the ageing population: Do older people have a place in driving up participation in sport? In: N. Rowe, ed. Driving up participation: The challenge for sport. London: Sport England. pp. 26-36. 
Luke, M. D. and Sinclair, G.D. , 1991. Gender differences in adolescents' attitudes towards school physical education. Journal of Teaching in Physical Education, 11, pp. 31-46.

Lundvall, S. , 2015. Physical literacy in the field of physical education: A challenge and a possibility. Journal of Sport and Health Science, 4(2), pp. 113-118.

Malina, R. M. , 1996. Tracking of physical activity and physical fitness across the lifespan. Research Quarterly for Exercise and Sport, 67(3 Supplement), pp. 48-57.

Matthews, P. , Xu, D. , Matusiak, M. and Prior, G. , 2016. Taking part: Findings from the longitudinal survey waves 1 to 3. TNS BMRB. London: Department for Culture Media and Sport.

McMurray, R. G. , Bradley, C. B. , Harrell, J. S. , Bernthal, P. R. , Frauman, A. C. and Bangdiwala, S. I. , 1993. Parental influences on childhood fitness and activity patterns. Research Quarterly for Exercise and Sport, 64(3), pp. 249-255.

McPherson, B. D. and Brown, B. A. , 1988. The structure, processes, and consequences of sport for children. In: F. L. Smoll , R. A. Magill, and M. J. Ash, eds. Children in sport. 3rd ed. Champaign, IL: Human Kinetics, pp. 265-286.

MORI , 2003. Young people and sport in England: 2002. London: Sport England.

Mulvihill, C. , Rivers, K. and Aggleton, P. , 2000. Views of young people towards physical activity: Determinants and barriers to involvement. Health Education, 100(5), pp. 190-199. http://dx.doi.org/10.1108/09654280010343555

Newman, B. and Newman, P. , 1995. Development through life: A psychosocial approach. New York: Brooks/Cole Publishing Co.

Ntoumanis, N. , 2001. A self determination approach to the understanding of motivation in physical education. British Journal of Educational Psychology, 71(2), pp. 225-242.

Ntoumanis, N. , 2002. Motivational clusters in a sample of British physical education classes. Psychology of Sport and Exercise, 3(3), pp. 177-194.

Office for National Statistics , 2013. What does the 2011 Census tell us about older people. Available at:

<www.ons.gov.uk/peoplepopulationandcommunity/birthsdeathsandmarriages/ageing>.

Pelletier, L. G. , Fortier, M. S. , Vallerand, R. J. , Tuson, K. M. , Briere, N. M. and Blais, M. R. , 1995. Toward a new measure of intrinsic motivation, extrinsic motivation, and amotivation in sports: The sports motivation scale (SMS). Journal of Sport and Exercise Psychology, 17(1), pp. 35-53.

Roberts, K. and Brodie, D. , 1992. Inner city sport: Who plays, and what are the benefits? Culemborg, The Netherlands: Giordano Bruno.

Roberts, K. , Minten, J. , Chadwick, C. , Lamb, K. and Brodie, D. , 1991. Sporting lives: A case study of leisure careers. Society and Leisure, 14(1), pp. 261-284.

Rowe, N. F. , 2012. An examination of the importance and satisfaction sports participants attach to volunteering support contextualized within a broader measure of satisfaction with the quality of the sporting experience. International Journal of Sport Policy and Politics, 4(2), pp. 159-172. http://dx.doi.org/10.1080/19406940.2012.656680

Rowe, N. F. , Adams, R. and Beasley, N. , 2004. Driving up participation in sport: The social context, the trends, the prospects and the challenges. In: N. Rowe, ed. Driving up participation: The challenge for sport. London: Sport England, pp. 6-13.

Rowe, N. F. and Radford, J. , Unpublished 2010. The social physics of sport-static, turbulence and volatility - and why these things matter. Sport England Internal Research Seminar Series.

Sallis, J. F. , Conway, T. L. , Prochaska, J. J. , McKenzie, T. L. , Marshall, S. J. and Brown, M. , 2001. The association of school environments with youth physical activity. American Journal of Public Health, 91(4), pp. 618-620.

Sallis, J. F. and McKenzie, T. L. , 1991. Physical education's role in public health. Research Quarterly for Exercise and Sport, 62(2), pp. 124-137.

Sallis, J. F. , Prochaska, J. J. , Taylor, W. C. , Hill, J. O. and Geraci, J. C. , 1999. Correlates of physical activity in a national sample of girls and boys in grades 4 through 12 . Health Psychology, 18(4), pp. 410-415.

Scheerder, J. , Thomis, M. , Vanreusel, B. , Lefevre, J., Renson, R. , Enynde, B. V. and Beunen, G. P. , 2005. Sports participation among females from adolescence to adulthood: A longitudinal study. International Review for the Sociology of Sport, 41(3), pp. 413-430.

Schutzer, K. A. and Graves, B. S. , 2004. Barriers and motivations to exercise in older adults. Preventive Medicine, 39(5), pp. 1056-1061. 
Scott, D. and Godbey, G. G. , 1992. An analysis of adult play groups: Social versus serious participation in contract bridge. Leisure Sciences, 14(1), pp. 47-67.

Shephard, R. J. and Trudeau, F. , 2000. The legacy of physical education: Influences on adult lifestyle. Pediatric Exercise Science, 12(1), pp. 34-50.

Slater, A. , 2011. Gender differences in adolescent sport participation, teasing, selfobjectification and body image concerns. Journal of Adolescence, 34(3), pp. 455-463.

Smith, A. L. , 1999. Perceptions of peer relationships and physical activity participation in early adolescence. Journal of Sport and Exercise Psychology, 21(4), pp. 329-350.

Stodden, D. F. , Goodway, J. D. , Langendorfer, S. J. , Roberton, M. A. , Rudisill, M. E. , Garcia, C. and Garcia, L. E. , 2008. A developmental perspective on the role of motor skill competence in physical activity: An emergent relationship. Quest, 60(2), pp. 290-306.

http://dx.doi.org/10.1080/00336297.2008.10483582

Stuij, M. , 2015. Habitus and social class: A case study on socialisation into sports and exercise. Sport, Education and Society, 20(6), pp. 780-798.

http://dx.doi.org/10.1080/13573322.2013.827568

Tammelin, T. , Näyhä, S. , Hills, A. P. and Järvelin, M. R. , 2003. Adolescent participation in sports and adult physical activity. American Journal of Preventive Medicine, 24(1), pp. 22-28.

Taylor, I. M. , Ntounamis, N. , Standage, M. and Spray, C. M. , 2010. Motivational predictors of physical education students' effort, exercise intentions and leisure-time physical activity: A multilevel linear growth analysis. Journal of Sport \& Exercise Psychology, 32(1), pp. 99-120.

Telama, R. , 1998. Psychological background of a physically active lifestyle among European youth. In: R. Naul , K. Hardman, M. Pieron, and B. Skirsted, eds. Physical activity and active lifestyles of children and youth. Schorndorf: Karl Hofmann, pp. 63-74.

Telama, R. , Yang, X. , Hirvensalo, M. and Raitakari, O. , 2006. Participation in organised youth sport as a predictor of adult physical activity: A 21 year longitudinal study. Pediatric Exercise Science, 17, pp. 76-88.

Telama, R. , Yang, X. , Laakso, L. and Viikari, J. , 1997. Physical activity in childhood and adolescence as predictor of physical activity in young adulthood. American Journal of Preventive Medicine, 13(4), pp. 317-323.

Ulrich, B. D. , 1987. Perceptions of physical competence, motor competence, and participation in organized sport: Their interrelationships in young children. Research Quarterly for Exercise and Sport, 58(1), pp. 57-67.

Van Bottenburg, M. , Rijnen, B. and van Sterkenburg, J. , 2005. Sports participation in the European Union: Trends and differences. Nieuwegein, Netherlands: Arko Sports Media.

Vanreusel, B. , Renson, R. , Beunen, G. , Claessens, A. L. , Lefevre, J. , Lysens, R. and Eynde, B. V. , 1997. A longitudinal study of youth sport participation and adherence to sport in adulthood. International Review for the Sociology of Sport, 32(4), pp. 373-387.

Van Tuyckom, C. , Scheerder, J. and Bracke, P. , 2010. Gender and age inequalities in regular sports participation: A cross-national study of 25 European countries. Journal of Sports Sciences, 28(10), pp. 1077-1084. http://dx.doi.org/10.1080/02640414.2010.492229

Viira, R. and Raudsepp, L. , 2000. Achievement goal orientations, beliefs about sport success and sport emotions as related to moderate to vigorous physical activity of adolescents.

Psychology and Health, 15(5), pp. 625-633.

Wankel, L. M. , 1993. The importance of enjoyment to adherence and psychological benefits from physical activity. International Journal of Sport Psychology, 24(2), pp. 151-169.

Wankel, L. M. and Kreisel, P. S. J. , 1985. Factors underlying enjoyment of youth sports: Sport and age group comparisons. Journal of Sport Psychology, 7(1), pp. 51-64.

Wearing, B. , 1995. Leisure and resistance in an ageing society. Leisure Studies, 14(4), pp. 263-279.

Weiss, M. R. , 1987. Self esteem and achievement in children's sport and physical activity. In: D. Gould and M. R. Weiss, eds. Advances in pediatric sport sciences, vol. 2: Behavioural issues. Champaign, IL: Human Kinetics, pp. 87-119.

Weiss, M. R. , 2013. Back to the future: Research trends in youth motivation and physical activity. Pediatric Exercise Science, 25(4), pp. 561-572.

Weiss, M. R. and Smith, A. L. , 2002. Friendship quality in youth sport: Relationship to age, gender and motivational variables. Journal of Sport and Exercise Psychology, 24(4), pp. 420-437. 
Whitehead, M. ed., 2010. Physical literacy throughout the lifecourse. London: Routledge. Wickstrom, R. , 1983. Fundamental motor patterns. 3rd ed. Philadelphia: Lea \& Febiger. Widdop, P. , Cutts, D. and Jarvie, G. , 2016. Omnivorousness in sport: The importance of social capital and networks. International Review for the Sociology of Sport, 51(5), pp. 596-616. Wilkinson, S. , Littlefair, D. and Barlow-Meade, L. , 2013. What is recognised as ability in physical education? A systematic appraisal of how ability and ability differences are socially constructed within mainstream secondary school physical education. European Physical Education Review, 19(2), pp. 147-164.

Williamson, D. F. , Kahn, H. S. , Remington, P. L. and Anda, R. F. , 1990. The 10-year incidence of overweight and major weight gain in U.S. adults. Archives of Internal Medicine, 150(3), pp. 665-672.

Wold, B. and Anderssen, N. , 1992. Health promotion aspects of family and peer influences on sport participation. International Journal of Sport Psychology, 23(4), pp. 343-359.

Women's Sport and Fitness Foundation , 2012. Changing the game for girls. Available at: <http://wsff.org.uk/sites/wsff.org.uk/files/Changing_The_Game_For_Girls_Final_0.pdf>.

Wood, L. and Danylchuk, K. , 2011. Playing our way: Contributions of social groups to women's continued participation in golf. Leisure Sciences, 33(5), pp. 366-381.

Wrotniak, B. H. , Epstein, L. H. , Dorn, J. M. , Jones, K. E. and Kondilis, V. A. , 2006. The relationship between motor proficiency and physical activity in children. Pediatrics, 118(6), pp. e1758-e1765.

Yang, X. , Telama, R. and Laakso, L. , 1996. Parents' physical activity, socio-economic status and education as predictors of physical activity and sport among children and youth: A 12 year follow up study. International Review for the Sociology of Sport, 31(3), pp. 273-291.

\section{Sporting capital in England}

Fox, K. R. and Corbin, C. , 1989. The physical self-perception profile: Development and preliminary validation. Journal of Exercise and Sport Psychology, 11(4), pp. 408-430. Nordern, O. , 2013. Creating sporting capital scores: Technical document. London: BMRB. Resnick, B. and Jenkins, L. , 2000. Testing the reliability and validity of the self-efficacy for exercise scale. Nursing Research, 49(3), pp. 154-159.

Rose, R. , Devalin, D. and O'Reilly, K. , 2005. The national statistics socio-economic classification: Origins, development and use. National Statistics. London: Pal-grave Macmillan. Rowe, N. F. , 2009. The active people survey: A catalyst for transforming evidence-based sport policy in England. International Journal of Sport Policy and Politics, 1(1), pp. 89-98. http://dx.doi.org/10.1080/19406940802681244

Sport England, 2016. Available at: <www.sportengland.org/news-andfeatures/news/2016/december/8/record-numbers-of-women-getting-active> [accessed 16th May 2017].

Sport England , 2017. Active lives survey year 1 report. Available at: <www.sportengland.org/media/11498/active-lives-survey-yr-1-report.pdf> [accessed 16th May 2017].

\section{Building sporting capital}

Bouchal, P. and Norris, E. , n.d. Implementing sure start children's centres. Joseph Rowntree Foundation and Institute for Government. Available at:

<www.instituteforgovernment.org.uk/sites/default/files/publications/Implementing\%20Sure\%20S tart\%20Childrens\%20Centres\%20-\%20final_0.pdf> [accessed 27th June 2017].

Cavill, N. and Baumann, A. , 2004. Changing the way people think about health-enhancing physical activity: Do mass media campaigns have a role? Journal of Sports Sciences, 22(8), pp. 771-790.

Collins, M. , 1988. Discussion on campaigns. Unpublished internal communication while Head of Research at Sport England. Included in slide presentation by Rowe, N. 'Sports Council 
campaigns-the lessons learned - a cautionary tale'. Presentation originally prepared by Nick Rowe in 1998 and updated 2003.

Department of Health , 2011. Start active, stay active: A report on physical activity from the four home countries' Chief Medical Officers. London: H.M. Government.

H. M. Government , 2015. Sporting future: A new strategy for an active nation. London: Cabinet Office.

Houlihan, B. and White, A. , 2002. The politics of sport development: Development of sport or development through sport? London: Routledge.

Let's Move! Child Care, n.d. Available at: <https://healthykidshealthyfuture.org> [accessed 14th June 2017].

Mills, C. W. , 1959. The sociological imagination. London: Oxford University Press.

Shape America, n.d. Available at: <www.shapeamerica.org/about> [accessed 14th June 2017]. Sport England , 2016. Sport England: Towards an active nation, strategy 2016-2021. London: Sport England.

Sport England , 2017. This girl can. Available at: <www.sportengland.org/our-work/women/thisgirl-can>.

UK Active, n.d. Start young, stay active. Childhood Physical Literacy Report. Available at: $<$ www.ukactive.com/downloads/managed/Start_Young_Stay_Active.pdf $>$ [accessed 18th June 2017].

Youth Sport Trust, n.d. Primary school physical literacy framework. Available at: $<$ www.youthsporttrust.org/sites/yst/files/resources/documents/physical_literacy_framework.pdf> [accessed 18th June 2017].

Youth Sport Trust , 2017. Early years physical literacy framework. Available at:

$<w w w$.activematters.org/uploads/pdfs/PLF_APRIL_2017.pdf $>$ [accessed 18th June 2017].

\section{Where do we go from here? Applying, refining and testing the model of sporting capital}

Chatterji, M. , 2016. Causal inferences on the effectiveness of complex social programs: Navigating assumptions, sources of complexity and evaluation design challenges. Evaluation and Program Planning, 59, pp. 128-140.

Chen, H. T. , 1989. The conceptual framework of the theory-driven perspective. Evaluation and Program Planning, 12, pp. 391-396.

Coalter, F. , 2007. A wider social role for sport: Who's keeping the score. London: Routledge. Donaldson, S. I. , 2007. Program theory-driven evaluation science. New York: Lawrence Erlbaum.

Everitt, A. , 1996. Developing critical evaluation. Evaluation, 2(2), pp. 173-188.

Nordern, O. , 2013. Creating sporting capital scores: Technical document. London: BMRB.

Pawson, R. , 2006. Evidence-based policy: A realist perspective. London: Sage.

Pawson, R. and Tilley, N. , 1997. Realistic evaluation. London: Sage.

Weiss, C. H. , 1995. Nothing as practical as a good theory: Exploring theory-based evaluation for comprehensive community initiatives for children and families. In: J. P. Connell , A. C. Kubisch, L. B. Schorr, and C. H. Weiss, eds. New approaches to evaluating community initiatives, vol. 1: Concepts, methods, and contexts. New York: Aspen Institute, pp. 65-92. Weiss, C. H. , 1997. How can theory-based evaluation make greater headway? Evaluation Review, 21(4), pp. 501-524. 